Prepared for the U.S. Department of Energy

under Contract DE-AC05-76RL01830

\title{
Laboratory-Scale Melter for Determination of Melting Rate of Waste Glass Feeds
}

D Kim

MJ Schweiger

WC Buchmiller

J Matyas

January 2012

Pacific Northwest

NATIONAL LABORATORY

Proudly Operated by Battelle Since 1965 


\title{
DISCLAIMER
}

This report was prepared as an account of work sponsored by an agency of the United States Government. Neither the United States Government nor any agency thereof, nor Battelle Memorial Institute, nor any of their employees, makes any warranty, express or implied, or assumes any legal liability or responsibility for the accuracy, completeness, or usefulness of any information, apparatus, product, or process disclosed, or represents that its use would not infringe privately owned rights. Reference herein to any specific commercial product, process, or service by trade name, trademark, manufacturer, or otherwise does not necessarily constitute or imply its endorsement, recommendation, or favoring by the United States Government or any agency thereof, or Battelle Memorial Institute. The views and opinions of authors expressed herein do not necessarily state or reflect those of the United States Government or any agency thereof.

\author{
PACIFIC NORTHWEST NATIONAL LABORATORY \\ operated by \\ BATTELLE \\ for the \\ UNITED STATES DEPARTMENT OF ENERGY \\ under Contract DE-AC05-76RL01830
}

Printed in the United States of America
Available to DOE and DOE contractors from the
Office of Scientific and Technical Information,
P.O. Box 62, Oak Ridge, TN 37831-0062;
ph: (865) 576-8401
fax: (865) 5765728
email: reports@adonis.osti.gov

\author{
Available to the public from the National Technical Information Service, \\ U.S. Department of Commerce, 5285 Port Royal Rd., Springfield, VA 22161 \\ ph: (800) 553-6847 \\ fax: (703) 605-6900 \\ email: orders@nits.fedworld.gov \\ online ordering: http://www.ntis.gov/ordering.htm
}


PNNL-21005

EMSP-RPT-012

\title{
Laboratory-Scale Melter for Determination of Melting Rate of Waste Glass Feeds
}

\author{
D Kim \\ MJ Schweiger \\ WC Buchmiller \\ J Matyas
}

January 2012

Prepared for

the U.S. Department of Energy

under Contract DE-AC05-76RL01830

Pacific Northwest National Laboratory

Richland, Washington 99352 



\section{Summary}

The purpose of this study was to develop the laboratory-scale melter (LSM) as a quick and inexpensive method to determine the processing rate of various waste glass slurry feeds. The LSM uses a 3 or 4 in. diameter-fused quartz crucible with feed and off-gas ports on top. This LSM setup allows cold-cap formation above the molten glass to be directly monitored to obtain a steady-state melting rate of the waste glass feeds. Major modifications to the previous LSM setup were implemented in the present study primarily to improve the view of the cold-cap melting progress.

The melting rate data from extensive scaled-melter tests with Hanford Site high-level wastes performed for the Hanford Tank Waste Treatment and Immobilization Plant have been compiled. Preliminary empirical model that expresses the melting rate as a function of bubbling rate and glass yield was developed from the compiled database. The two waste glass feeds with most melter run data-for AZ-101 and C-106/AY-102 wastes - were selected for detailed evaluation and model development and for the LSM tests so the melting rates obtained from LSM tests can be compared with those from scaled-melter tests.

The present LSM results suggest the LSM setup can be used to estimate the appropriate trends in glass production rates for the development of new glass compositions or feed makeups that are designed to increase the processing rate of the slurry feeds, although it will not give a quantitative data of large-scale tests. The improvements applied to the present LSM setup will also be valuable for investigating the formation of separated salt phase during cold-cap melting, which is required to develop glass formulations for the waste types of which loading is limited by separated salt formation. 



\section{Acknowledgments}

The authors are grateful to the U.S. Department of Energy's Environmental Management, Office of Waste Processing (EM-31), for initial funding of the project and for the Office of River Protection and

Washington River Protection Solutions for their continued support. Programmatic directions by Steve Schneider and Gary Smith at EM-31 and technical support by Albert Kruger at the U.S. Department of Energy’s Office of River Protection are greatly appreciated. 



\section{Acronyms and Abbreviations}

$\begin{array}{ll}\text { DOE } & \text { U.S. Department of Energy } \\ \text { DWPF } & \text { Defense Waste Processing Facility } \\ \text { EM } & \text { U.S. Department of Energy, Office of Environmental Management } \\ \text { EM-31 } & \text { U.S. Department of Energy, Office of Waste Processing } \\ \text { GC-MS } & \text { gas chromatography-mass spectrometry } \\ \text { HLW } & \text { high-level waste } \\ \text { LSM } & \text { laboratory-scale melter } \\ \text { OD } & \text { outer diameter } \\ \text { PNNL } & \text { Pacific Northwest National Laboratory } \\ \text { SEM } & \text { scanning electron microscope } \\ \text { VSL } & \text { Vitreous State Laboratory at the Catholic University of America } \\ \text { WP } & \text { waste processing } \\ \text { WTP } & \text { Hanford Tank Waste Treatment and Immobilization Plant }\end{array}$





\section{Contents}

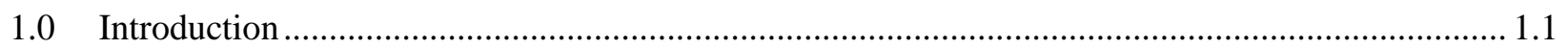

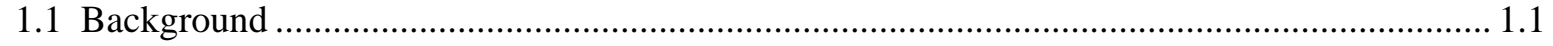

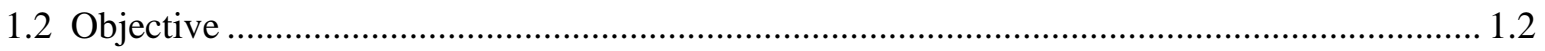

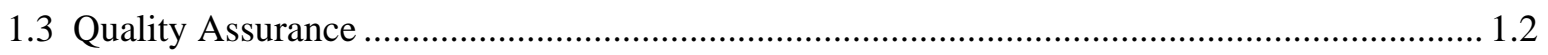

2.0 Melting Rate Data from Melter Tests ...................................................................................... 2.1

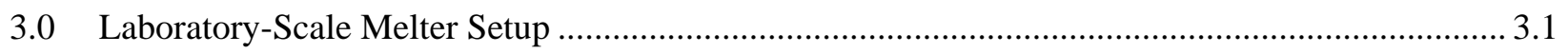

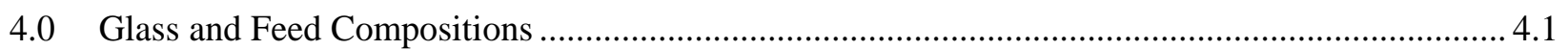

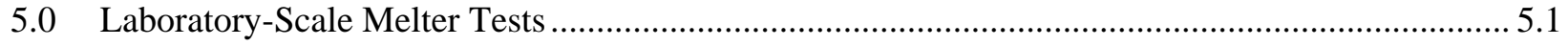

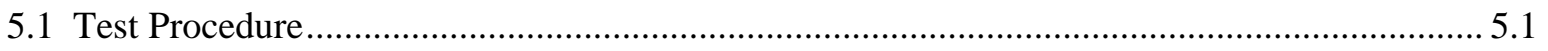

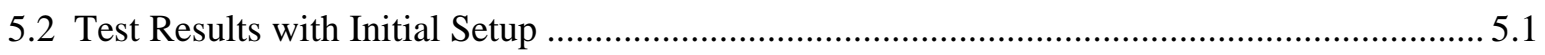

5.3 Test Results with Improved Setup …............................................................................... 5.3

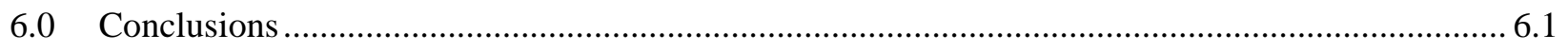

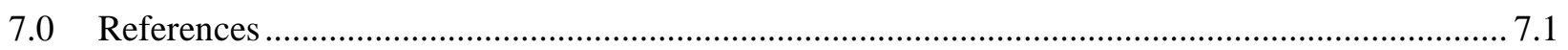




\section{Figures}

1.1. Schematic of Cold-Cap Melting in Joule Heated Melter .......................................................... 1.1

2.1. Predicted Versus Measured Glass Production Rate from DM1000/1200 Tests............................. 2.3

2.2. Predicted Glass Production Rate as a Function of Glass Yield (upper plot) and Normalized

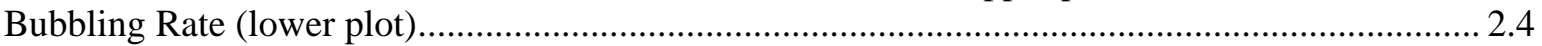

2.3. Predicted Versus Measured Glass Production Rate from DM1000/1200 and DM100 Tests .......... 2.5

3.1. Schematic of LSM Used by Riley et al. (2009) ........................................................................... 3.1

3.2. Schematic of Modified LSM Used in This Study ......................................................................... 3.3

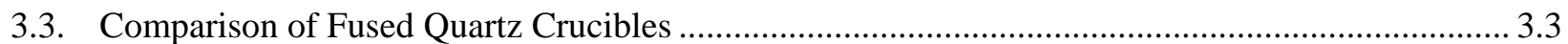

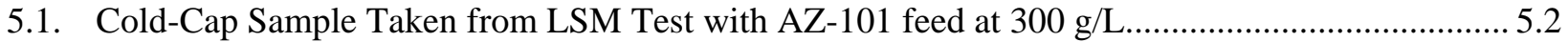

5.2. Example of Cold-Cap Sample Analyses: (a) picture of glass-cold cap sample from LSM test with AZ-101 feed at $300 \mathrm{~g} / \mathrm{L}$; (b) and (c) SEM micrographs of the areas indicated in (a); (d) high magnification SEM micrograph of area indicated in (b) with phases identified ......... 5.3

5.3. Pictures Showing the Sequence of Melting the AZ-101 Glass Cullet during Ramp Heating Before Adding the Slurry Feed ............................................................................................. 5.4

5.4. Picture Showing the Initial Stage of Cold-Cap Formation After Adding the Slurry Feed............... 5.4

5.5. Pictures Showing the Steady State Cold-Cap with Large Bubbles Bursting Through Glass Melt Around the Cold Cap ......................................................................................................... 5.5

5.6. Pictures of Glass Samples with Quenched Cold-Caps on Top After LSM Tests ........................... 5.6

5.7. Melting Rates Measured from LSM Tests Compared with Predicted Melting Rates for DM1200 and DM100 Calculated by Equations (1) and (2) ........................................................ 5.7

5.8. Predicted Versus Measured Glass Production Rate for Simulated AZ-101 Melter Feeds............... 5.9

5.9. Predicted Effect of Melter Surface Area on Glass Production Rate .............................................. 5.9

5.10. Glass Temperature versus Time after the Start of Feeding .......................................................... 5.10

5.11. Plenum Temperature Versus Time After the Start of Feeding .................................................... 5.10

5.12. Glass and Plenum Temperatures Versus Glass Production Rate ................................................ 5.11 


\section{Tables}

2.1. Glass Production Rate for Melter Feeds with Simulated AZ-101 and C-106/AY-102 Wastes from DM1000 and DM1200 Tests.

2.2. Glass Production Rate for Melter Feeds with Simulated AZ-101 and C-106/AY-102 Wastes from DM100 Tests

2.3. Model Coefficients for Glass Production Rate in DM1200 Tests with Two Hanford HLW Feeds

4.1. Composition of Glasses Formulated for Simulated AZ-101 and C-106/AY-102 Wastes Selected for LSM Tests

4.2. Composition of AZ-101 Waste Glass Feeds Selected for LSM Tests ......

4.3. Composition of C-106/AY-102 Waste Glass Feeds Selected for LSM Tests.

5.1. Measured Density of LSM Feeds

5.2. Calibrated Feeding Rates for LSM Feeds

5.3. Steady-State Feed Rate and Melting Rate from LSM Tests 5.7

5.4. Model Coefficients for Glass Production Rate from DM1000/DM1200, DM100, and LSM Tests with AZ-101 Feeds 



\subsection{Introduction}

\subsection{Background}

The cost and schedule of high-level waste (HLW) treatment is highly dependent on the loading of HLW in glass and on the rate of HLW glass production. Increasing the rate of glass processing in the Hanford Tank Waste Treatment and Immobilization Plant (WTP) at the Hanford Site and in the Defense Waste Processing Facility (DWPF) at the Savannah River Site will allow shortening the life cycle of waste cleanup at each site.

In a continuous glass melter, the rate of processing is jointly controlled by the rate of heat-transfer from molten glass to the cold cap and by the kinetics of various chemical reactions and phase transitions within the cold cap (Bickford et al. 1990; Hrma 1990; Hrma et al. 2002). The cold cap is a mixture of low-melting salts, glass forming melts, undissolved refractory solids (sometimes in clusters), and various gases. Figure 1.1 shows a schematic of cold-cap melting in a Joule-heated ceramic melter. With an increasingly effective heat transfer in advanced melters equipped with bubblers, the kinetics of feed-toglass conversion reactions within the cold cap becomes more prominent as the rate-controlling process. Thus, the glass formulation and makeup of the feed-i.e., the selection and pretreatment of the batch materials-becomes more important for melting efficiency.

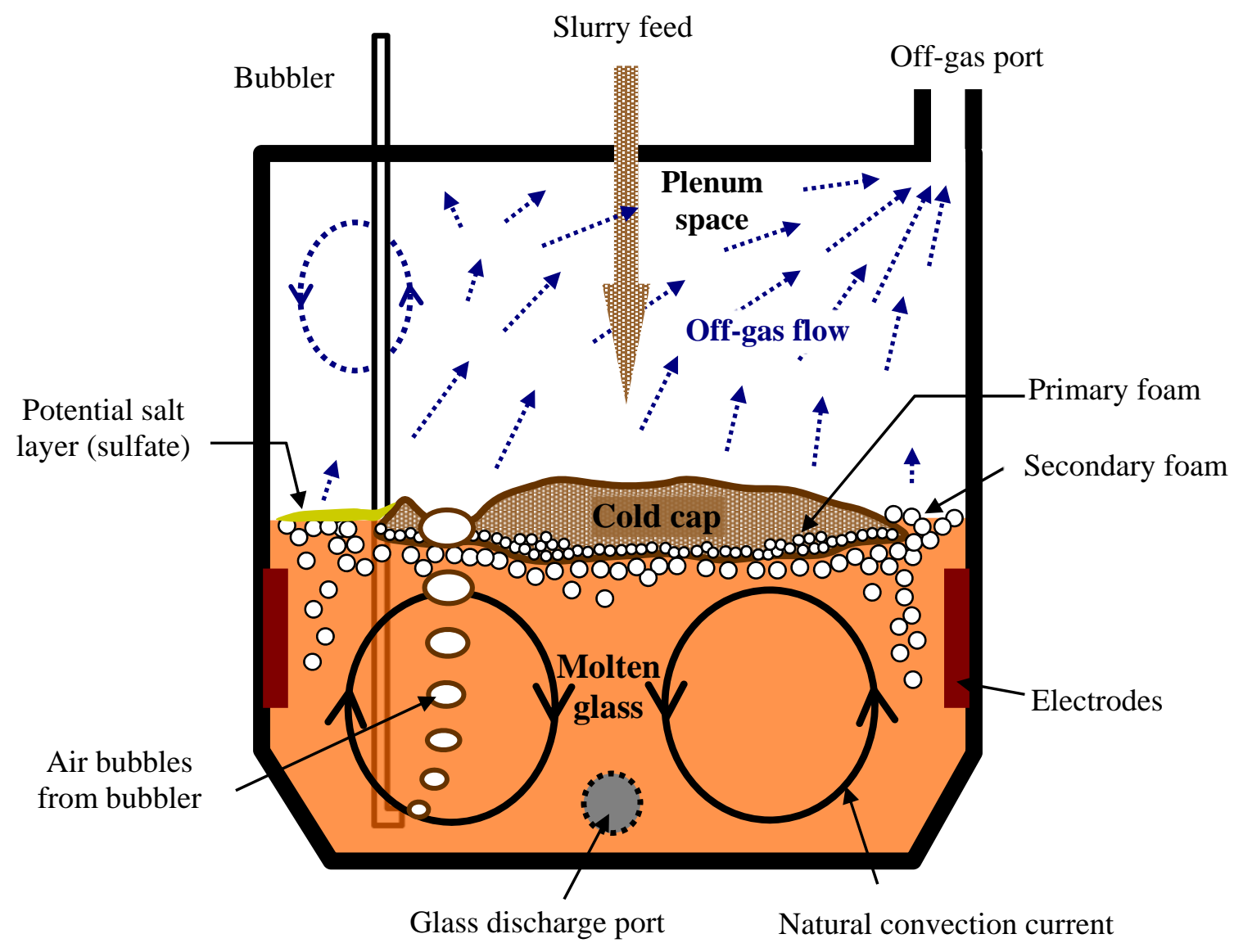

Figure 1.1. Schematic of Cold-Cap Melting in Joule Heated Melter (cross-section view) 
Model-based glass formulation tools have been developed so that each melter feed batch is formulated to satisfy all glass quality and basic processing requirements with appropriate confidence. However, there is currently no tool that can adequately predict the feed melting behavior including the rate of melting as a function of melter feed composition. Therefore, before defining the glass-forming chemicals or frit for a specific batch, the melting rate is assessed through experimental studies, which can be time consuming and costly. Having models to predict the melting behavior of the feed would have a significant impact on glass formulation developed with respect to not only cost but also schedule.

Melting rate studies are being performed at Pacific Northwest National Laboratory (PNNL) to develop a fundamental understanding of glass conversion reactions - in particular those that strongly influence the rate of melting, and tools to predict the impacts of composition and other key parameters on the melting rate, which will be used to identify the methods and strategy to increase the throughput of HLW feeds. The initial results of the crucible scale tests of cold-cap processes to express the key cold-cap parameters that are important to cold-cap behavior as a function of glass feed composition and selected physical properties have been published (Hrma et al. 2009, 2010, 2011a, 2011b; Schweiger et al. 2009; Henager et al. 2011). The results of crucible scale tests are being used as model inputs for the mathematical cold-cap model. The model report published by Pokorny and Hrma (2010) summarized the recent progress in the development of mathematical model that can, once fully developed, predict melting rates based on feed composition and various processing conditions.

This report describes the development of a laboratory-scale melter (LSM) that can be used to determine the rate of melting for various slurry feeds for the vitrification of HLW. The LSM uses a 3 or 4 in. diameter-fused quartz crucible with feed and off-gas ports on top. This LSM setup allows cold-cap formation above the molten glass to be directly monitored to obtain a steady-state melting rate of the waste glass feeds. The LSM can also be used as a quick and inexpensive method to evaluate the cold-cap melting behavior of a range of newly formulated feeds for various purposes, such as formation of salt phase on molten glass surfaces.

\subsection{Objective}

The objective of this study is to establish LSM as a tool to determine the processing rate of waste glass feeds that qualitatively mimic those from large-scale melter tests. LSM tests were performed using Hanford Site HLW glass feeds with existing processing rate data from scaled-melter tests so that the melting rate determined from the LSM test could be compared with that obtained from scaled-melter tests.

\subsection{Quality Assurance}

A graded quality assurance approach was used for the Waste Processing No.4 (WP-4) tasks performed under the U.S. Department of Energy EM-31 Technology Development and Deployment program. The work activities performed in the WP-4.2.2 subtask were performed in accordance with the quality assurance plan for the EM-31 Support Project (EM-31SP-PQAP) under Quality Level 3. This work was conducted in accordance with best laboratory practices (NQA-1-2000-based) as implemented through PNNL's standards-based management system (How-Do-I [HDI]) work flows and subject areas. 


\subsection{Melting Rate Data from Melter Tests}

The results of extensive scaled-melter tests with Hanford Site HLWs performed at Vitreous State Laboratory (VSL) of the Catholic University of America for the WTP project (Matlack et al. 2000, 2001, 2003a, 2003b, 2003c, 2004a, 2004b, 2004c, 2005a, 2005b, 2005c, 2006, and 2007) have been compiled. This database was used to select simulated HLW glass and feed compositions for the LSM tests. Chapman (2004) and Perez et al. (2005) used the similar set of data to develop a mechanistic model that expressed the melting rate as a function of various parameters related to bubbling without considering the effect of feed variations. The present evaluation focused on a preliminary empirical model for melting rate as a function of bubbling rate and glass yield for different feed compositions. Table 2.1 and Table 2.2 summarize the melting rate data for given normalized bubbling rate and glass yield from DM1000/1200 (Table 2.1) and DM100 (Table 2.2) tests.

Table 2.1. Glass Production Rate for Melter Feeds with Simulated AZ-101 and C-106/AY-102 Wastes from DM1000 and DM1200 Tests

\begin{tabular}{|c|c|c|c|c|c|}
\hline Target Waste & Glass ID & Reference & $\begin{array}{l}\text { Bubbling } \\
\text { Rate }{ }^{(a)} \text {, } \\
\text { L/(m²min) }\end{array}$ & $\begin{array}{l}\text { Target Glass } \\
\text { Yield, } \\
\text { g/L }\end{array}$ & $\begin{array}{l}\text { Melting } \\
\text { Rate }^{(\mathbf{b})} \text {, } \\
\left.\text { kg/(m } \mathbf{m}^{2} \mathbf{d}\right)\end{array}$ \\
\hline \multirow{23}{*}{ AZ-101 } & \multirow{6}{*}{ HLW98-31 } & \multirow{2}{*}{ Matlack et al. 2000} & 0 & 300 & 180 \\
\hline & & & 0 & 570 & 260 \\
\hline & & \multirow{3}{*}{ Matlack et al. 2001} & 47.2 & 350 & 705 \\
\hline & & & 3.1 & 570 & 265 \\
\hline & & & 47.2 & 570 & 759 \\
\hline & & Matlack et al. 2003a & 3.3 & 570 & 272 \\
\hline & \multirow{17}{*}{ HLW98-77 } & \multirow{16}{*}{ Matlack et al. 2004a } & 57.5 & 300 & 477 \\
\hline & & & 6.7 & 300 & 235 \\
\hline & & & 33.3 & 300 & 471 \\
\hline & & & 54.2 & 300 & 672 \\
\hline & & & 0.8 & 400 & 177 \\
\hline & & & 6.7 & 400 & 271 \\
\hline & & & 33.3 & 400 & 481 \\
\hline & & & 54.2 & 400 & 709 \\
\hline & & & 6.3 & 530 & 406 \\
\hline & & & 21.7 & 530 & 627 \\
\hline & & & 35.8 & 530 & 797 \\
\hline & & & 54.2 & 530 & 986 \\
\hline & & & 60.8 & 530 & 941 \\
\hline & & & 6.7 & 530 & 412 \\
\hline & & & 33.3 & 530 & 648 \\
\hline & & & 54.2 & 530 & 875 \\
\hline & & Matlack et al. 2004c & 54.2 & 530 & 1038 \\
\hline \multirow{7}{*}{$\begin{array}{l}\text { C-106/ } \\
\text { AY-102 }\end{array}$} & \multirow{2}{*}{ HLW98-34 } & \multirow{2}{*}{ Matlack et al. 2000} & 0 & 510 & 160 \\
\hline & & & 79.2 & 510 & 810 \\
\hline & \multirow{5}{*}{ HLW98-86 } & \multirow{3}{*}{ Matlack et al. 2003b } & 6.7 & 518 & 329 \\
\hline & & & 33.3 & 518 & 484 \\
\hline & & & 54.2 & 518 & 894 \\
\hline & & \multirow{2}{*}{ Matlack et al. 2004b } & 54.2 & 550 & 926 \\
\hline & & & 54.2 & 550 & 777 \\
\hline
\end{tabular}


Table 2.2. Glass Production Rate for Melter Feeds with Simulated AZ-101 and C-106/AY-102 Wastes from DM100 Tests

\begin{tabular}{|c|c|c|c|c|c|}
\hline $\begin{array}{l}\text { Target } \\
\text { Waste }\end{array}$ & Glass ID & Reference & $\begin{array}{l}\text { Bubbling } \\
\text { Rate }^{(\mathbf{a})} \\
\text { L/(m² min) }\end{array}$ & $\begin{array}{c}\text { Target } \\
\text { Glass Yield, } \\
\text { g/L }\end{array}$ & $\begin{array}{l}\text { Melting } \\
\text { Rate }^{(\mathbf{b})} \text {, } \\
\mathbf{k g} /\left(\mathbf{m}^{2} \mathbf{d}\right)\end{array}$ \\
\hline \multirow{7}{*}{ AZ-101 } & \multirow{7}{*}{ HLW98-31 } & \multirow{7}{*}{ Matlack et al. 2003c } & 52.4 & 350 & 873 \\
\hline & & & 0.9 & 410 & 349 \\
\hline & & & 0.9 & 514 & 398 \\
\hline & & & 0.9 & 555 & 414 \\
\hline & & & 8.7 & 555 & 643 \\
\hline & & & 21.8 & 555 & 811 \\
\hline & & & 52.4 & 555 & 1233 \\
\hline \multirow{5}{*}{$\begin{array}{l}\text { C-106/ } \\
\text { AY-102 }\end{array}$} & \multirow{2}{*}{ HLW98-86 } & \multirow{2}{*}{ Matlack et al. 2007} & 83.3 & 534 & 827 \\
\hline & & & 83.3 & 533 & 882 \\
\hline & \multirow{3}{*}{ HLW04-09 } & \multirow{2}{*}{ Matlack et al. 2005c } & 82.4 & 423 & 1117 \\
\hline & & & 84.3 & 500 & 1183 \\
\hline & & Matlack et al. 2005a & 104.6 & 420 & 1356 \\
\hline
\end{tabular}

Only the tests with simulated AZ-101 and C-106/AY1-02 had sufficient number of data for evaluation of the effect of feed composition. Table 2.1 and Table 2.2 include only the tests that have all other test variables constant, except the bubbling rate and glass yield; i.e., the data from following tests were excluded:

- tests with modified operation conditions, e.g., modified bubbler configuration, nominal processing temperature other than $1150^{\circ} \mathrm{C}$, and use of plenum heating

- tests with modified feeds, e.g., addition of sucrose, use of glass frit, and adjusted feed rheology

- tests that resulted in abnormal conditions, e.g., vigorous foaming and steady state not obtained

- tests with outlying operation conditions, e.g., extremely high bubbling rate compared to the rest of the tests

- tests that used bubbling but did not report the bubbling rate.

Initially, the modeling effort in this study was performed on data from DM1000/1200 tests only. It was found that the glass production rate fits well to the function shown in Equation (1):

$$
r_{G, D M 1200}=\left(1+c_{B} r_{B}^{m}\right) c_{G} y_{G}^{n}
$$

where $\quad r_{G, D M 1200}=$ glass production rate $\left[\mathrm{kg} /\left(\mathrm{m}^{2} \mathrm{~d}\right)\right]$ from DM1000/1200 tests

$r_{B}=$ bubbling rate per unit melter surface area $\left[\mathrm{L} /\left(\mathrm{m}^{2} \mathrm{~min}\right)\right]$

$y_{G}=$ glass yield per unit volume of slurry feed $\left.\left(\mathrm{g}_{\text {(glass }}\right) / \mathrm{L}_{(\text {feed })}\right)$

$c_{B}$ and $c_{G}=$ coefficients dependent on melter feed

$m$ and $n=$ coefficients independent of melter feed

Table 2.3 shows the model coefficients calculated for the melter feeds for the simulated AZ-101 wastes (Matlack et al. 2000, 2001, 2003a, 2004a, 2004c) and for the simulated C-106/AY-102 wastes (Matlack et al. 2000, 2003b, 2004b). All six coefficients were obtained from a least-square regression for 
all 30 data points in Table 2.1. The $R^{2}$ value for the model was 0.923 . The plot of predicted versus measured production rate is in Figure 2.1. Figure 2.2 shows the predicted effects of glass yield and normalized bubbling rate on the calculated glass production rate.

Table 2.3. Model Coefficients for Glass Production Rate in DM1200 Tests with Two Hanford HLW Feeds

\begin{tabular}{|c|c|c|}
\hline Coefficient & AZ-101 & C-106/AY-102 \\
\hline$m$ & \multicolumn{2}{|c|}{0.70} \\
\hline$n$ & \multicolumn{2}{|c|}{0.78} \\
\hline$C_{B}$ & 0.21 & 0.20 \\
\hline$C_{G}$ & 1.54 & 1.34 \\
\hline
\end{tabular}

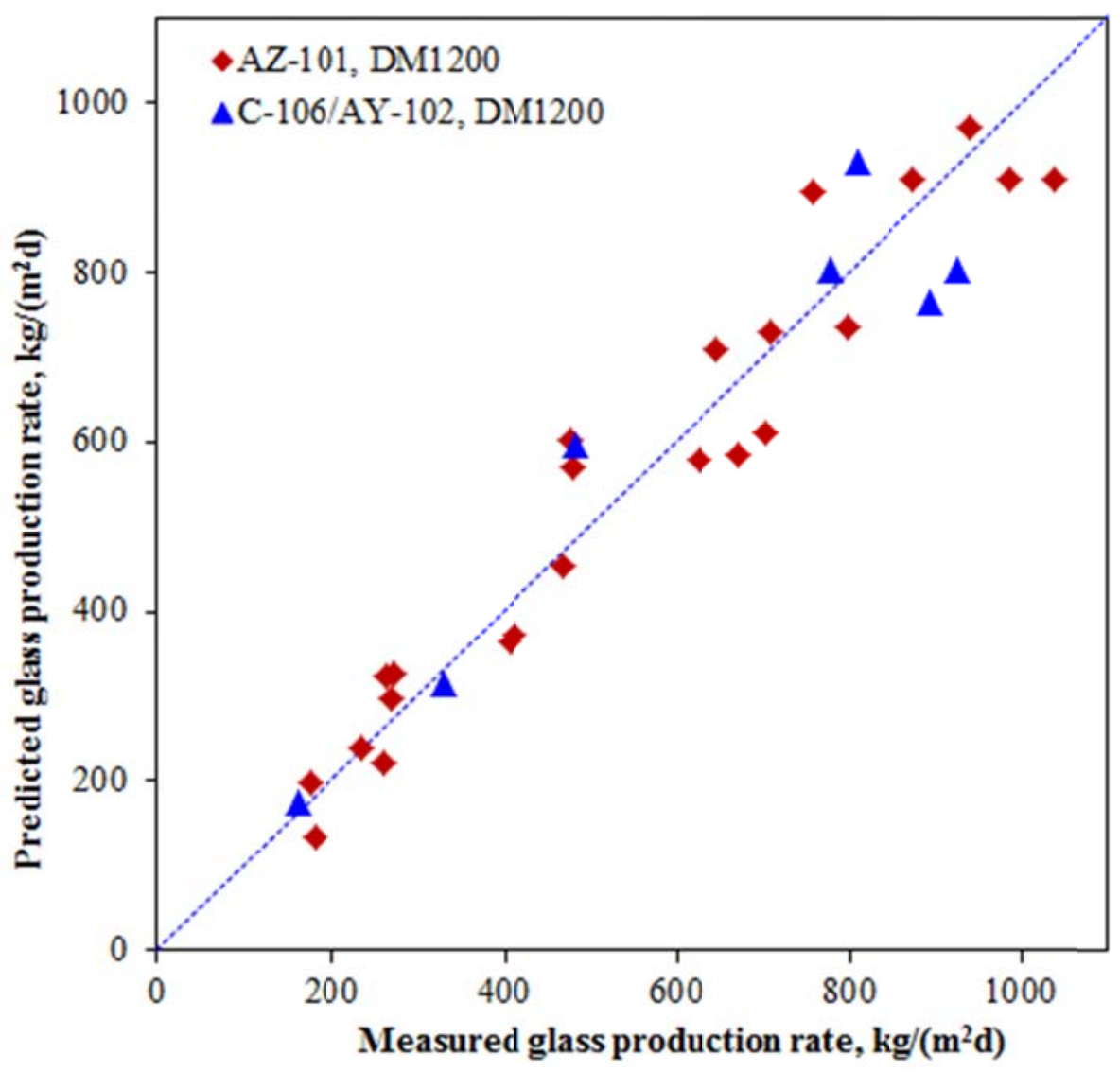

Figure 2.1. Predicted Versus Measured Glass Production Rate from DM1000/1200 Tests 

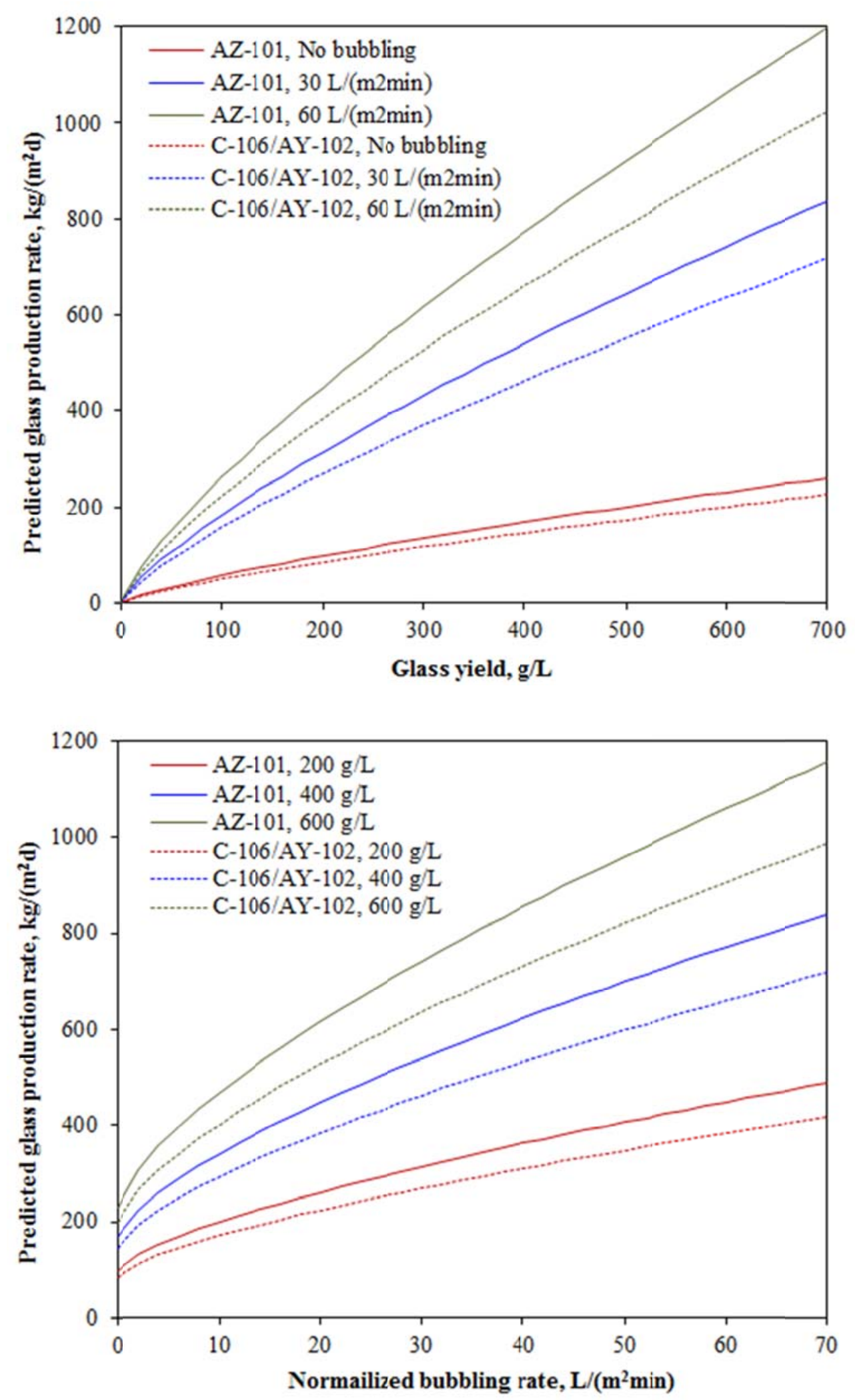

Figure 2.2. Predicted Glass Production Rate as a Function of Glass Yield (upper plot) and Normalized Bubbling Rate (lower plot) 
Table 2.3 and Figure 2.2 show that the processing rate is higher for the AZ-101 melter feeds (both $C_{B}$ and $c_{G}$ are larger) than the C-106/AY-102 melter feeds. There were not enough data to differentiate the effect of glass composition for the same waste (e.g., between HLW98-31 and HLW98-77 for AZ-101 glasses) or the difference was negligible. The exponents from the model for glass yield and normalized bubbling rate, $m$ and $n$, are smaller than 1 , and therefore the model predicts stronger effects of these variables at low bubbling rate and glass yield that diminishes as they increase as shown in Figure 2.2. For glass yield, the typical experimental range is from 300 to $600 \mathrm{~g} / \mathrm{L}$ for which the relationship between the predicted glass production rate and glass yield is close to linear.

Initial comparison of data from DM100 with those from DM1200 tests showed the melt surface area specific production rate was faster from DM100 tests under similar conditions. However, there were not sufficient data for a separate model with DM100 data. It was found that the following simple relation as shown in Equation (2) fits the data well:

$$
r_{G, D M 100}=f_{100} r_{G, D M 1200}
$$

where $r_{G, D M 100}$ is the glass production rate from DM100 tests. The fit of Equation (2) to the DM100 data given in Table 2.2 resulted in the $f_{100}$ values of 1.38 for AZ-101 feeds and 1.13 for C-106/AY-102 feeds. The plot of predicted versus measured production rate from DM1000/1200 and DM100 tests is in Figure 2.3.

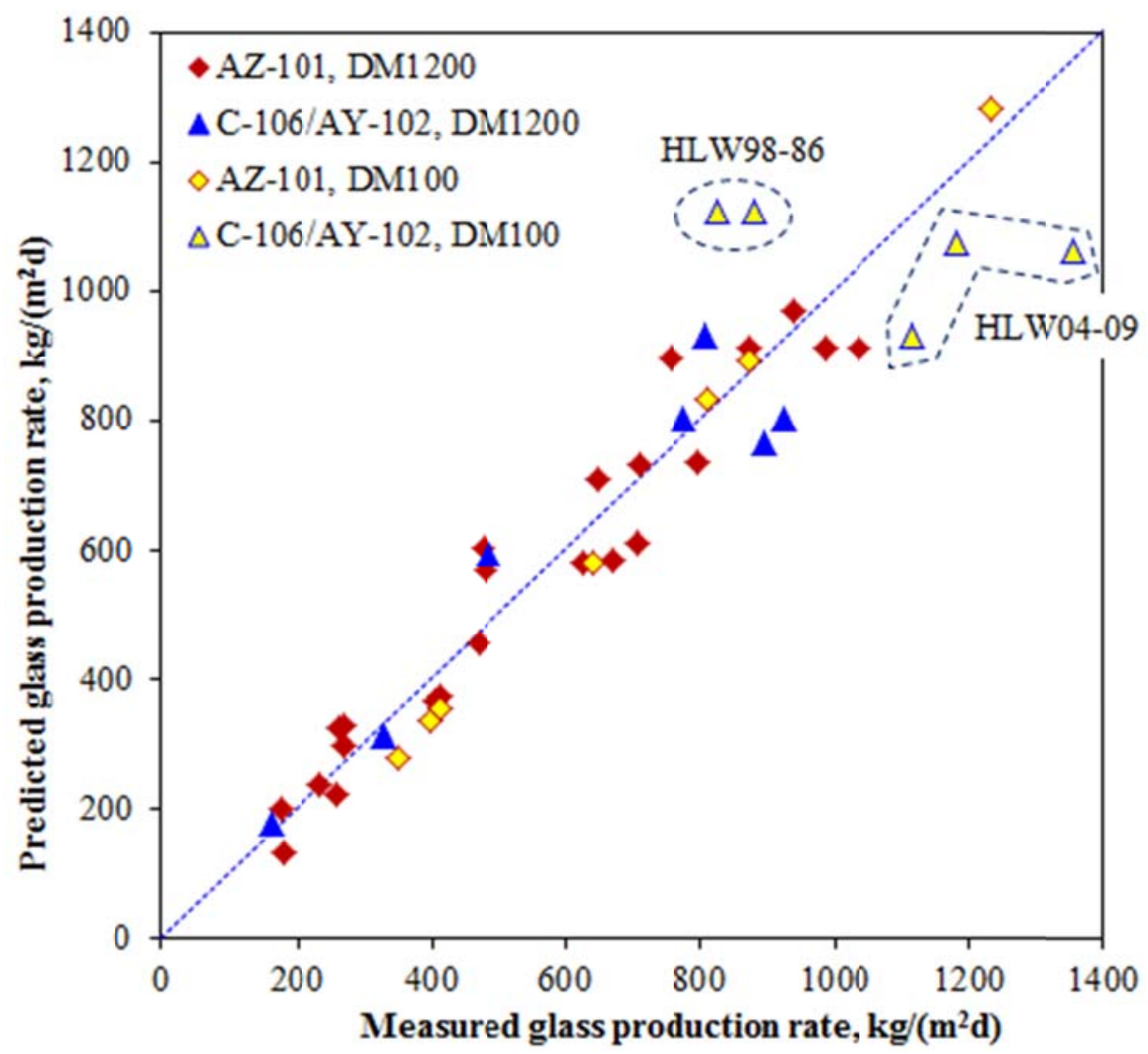

Figure 2.3. Predicted Versus Measured Glass Production Rate from DM1000/1200 and DM100 Tests 
Figure 2.3 shows that the DM100 results with AZ-101 feed fit Equation (2) exceptionally well but those with C-106/AY-102 feeds showed large scatter. For the C-106/AY-102 feeds, there was a clear difference in production rate between two glass compositions (HLW04-09 glass melted significantly faster than HLW98-86 under similar bubbling rate and glass yield). In addition, the variations for bubbling rate and glass yield for C-106/AY-102 feeds were very narrow, i.e., these variations are not good data sets for the model and therefore the resulting coefficient $\left(f_{100}=1.38\right)$ is not adequate for comparison with test data. 


\subsection{Laboratory-Scale Melter Setup}

The LSM setup that was developed at PNNL uses a fused quartz crucible as a small melter. This method allows cold-cap formation and evolution to be directly observed during slurry feeding and has been primarily used to evaluate the formation of a salt layer from various melter feeds (Darab et al. 2001; Vienna et al. 2002; Kim et al. 2003). This method has improved and evolved into the setup used by Riley et al. (2009).

The LSM assembly used in Riley et al. (2009) is shown schematically in Figure 3.1. The single-use fused quartz crucible melter bodies have $3 \mathrm{in.}$ OD and are $10 \mathrm{in}$. tall with two smaller ports (0.75 in. OD). The vertical tube is used as the feed inlet and the slanted tube for off-gas. To maintain the temperature of the cold-cap region in the melter constant, the hot zone of the crucible is continuously raised as the melt layer height is increased from feed processing. This assembly is capable of collecting off-gas samples for chemical analyses or can be connected to gas chromatography-mass spectrometry (GC-MS) for evolved gas analyses.

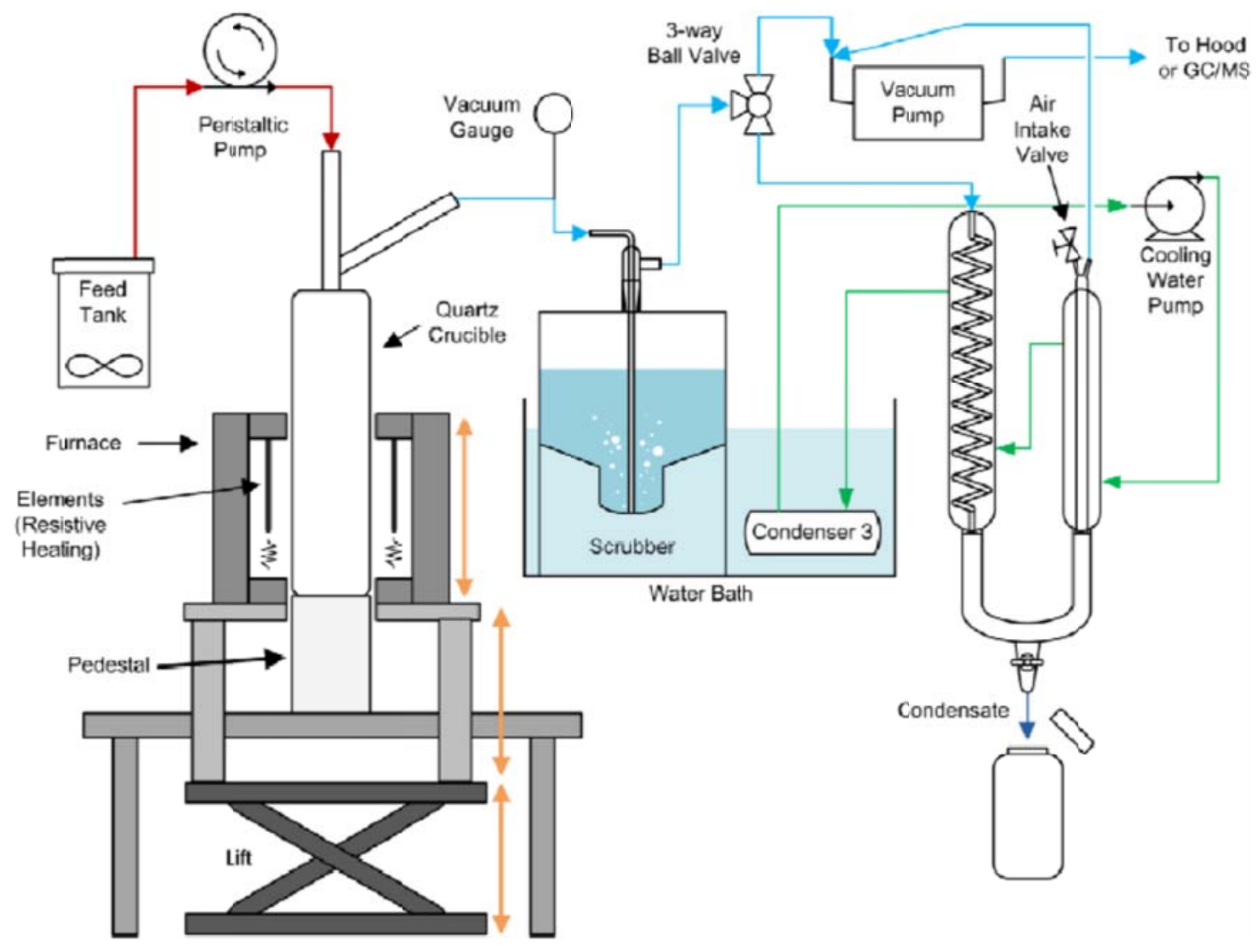

Figure 3.1. Schematic of LSM Used by Riley et al. (2009) 
The initial LSM tests in this study were performed after applying following modifications (shown in Figure 3.2):

- The off-gas system used to collect off-gas samples was removed and replaced by a simple vent system that sends the off gas to the hood and is designed to prevent the condensed water from flowing back into the crucible.

- The crucible position relative to the furnace was raised so that the melt is primarily heated from the bottom of the crucible (see Figure 3.2).

The preliminary LSM results provided information on the structure (morphology) of cold cap valuable to the development of the mathematical cold-cap model (Pokorny and Hrma 2010). However, the LSM setup was not sensitive enough for quantitative determination of melting rate for this study. The preliminary LSM tests identified several issues that made it difficult to obtain the steady state melting rate. Based on these initial experiences, the following improvements were implemented:

- Increased diameter of quartz crucible to allow more room for a cold cap to grow before it touches the crucible wall to avoid "bridging" of the cold cap, which, once formed, is very difficult to recover back to normal operation (see Figure 3.3).

- New lift apparatus to allow fine control and precise monitoring of crucible height so that the temperature at the interface between cold cap and molten glass can be kept reasonably constant during tests.

- Redesign of slurry feeding system to use water-cooled line outside the feeding tube so the feed nozzle can be brought closer to the cold cap without clogging the feed line caused by dried feed. The reason to bring the feed nozzle closer to the cold cap is to avoid splashing the slurry feed material to the top of the crucible that causes severe interference of view.

- Placement of thermocouple bundle for measurement of temperatures of the molten glass and plenum space (using the additional port added to new fused quartz crucible; see Figure 3.3). This port can also be used to insert the bubbler.

One of the key factors for successful operation was to keep the cold-cap coverage relatively low at about $40 \%$ so the steady state cold-cap coverage can be maintained without causing bridging. 


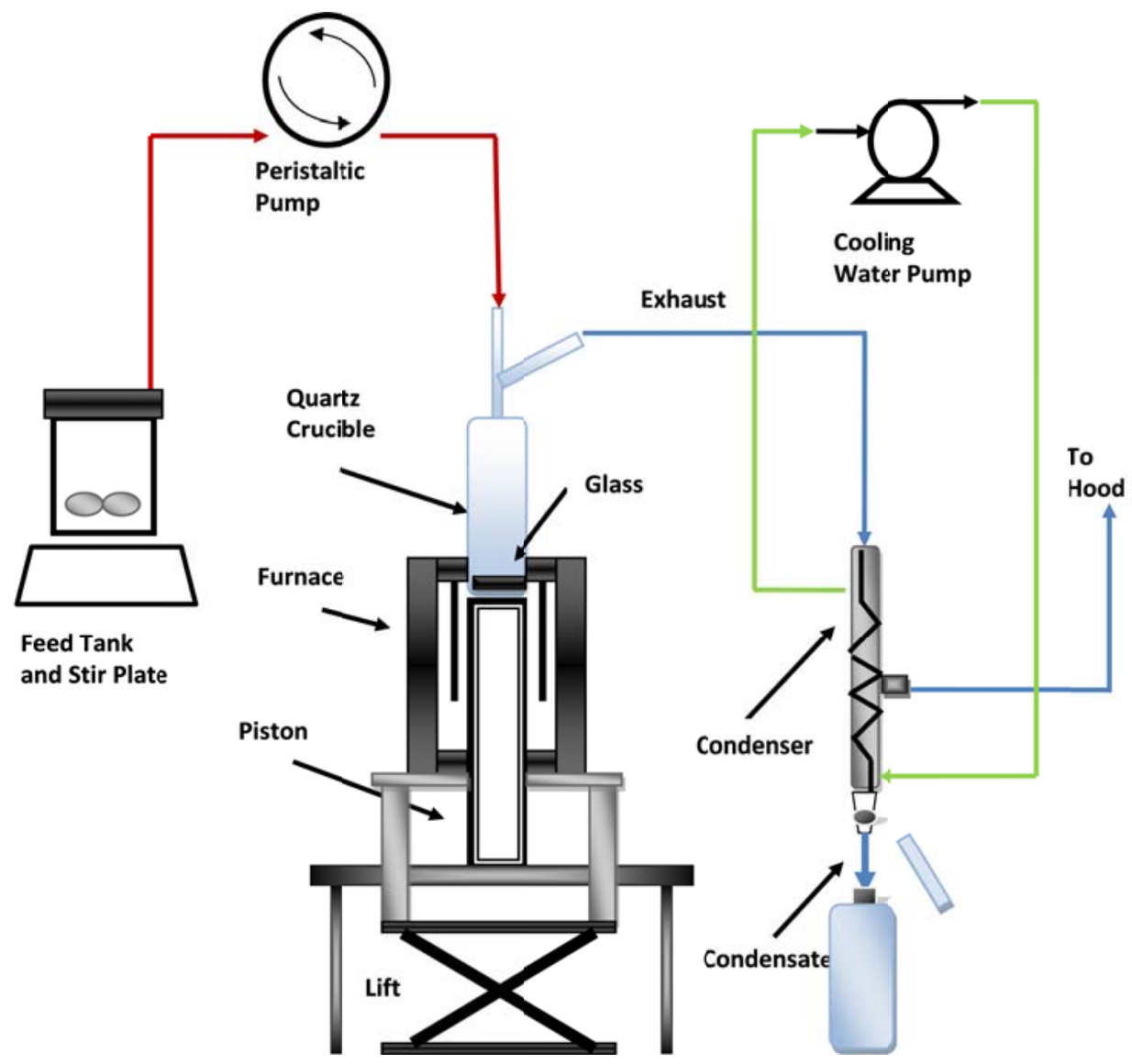

Figure 3.2. Schematic of Modified LSM Used in This Study
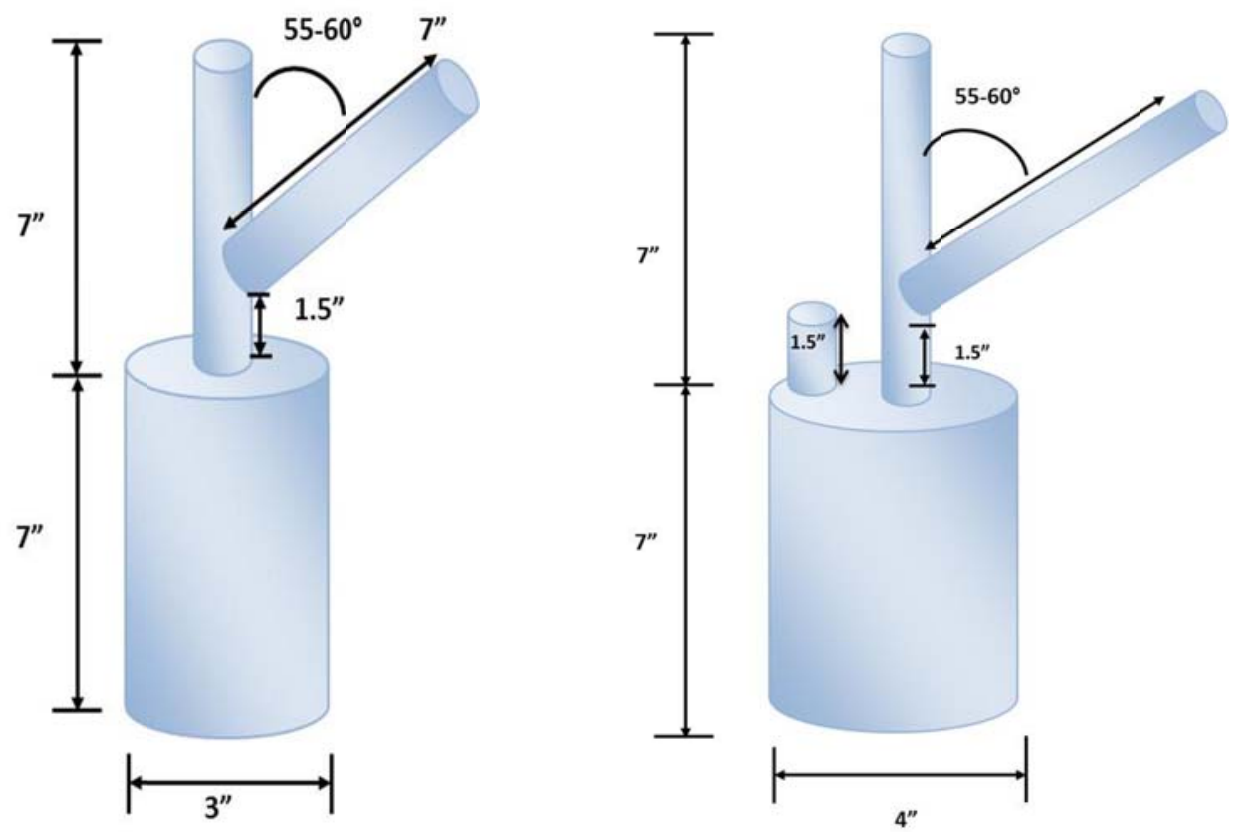

Figure 3.3. Comparison of Fused Quartz Crucibles (left image is old; right image is new) 



\subsection{Glass and Feed Compositions}

Based on existing melting rate data from scaled-melter tests discussed in Section 2.0, the two glasses were selected for the LSM tests- HLW98-77 for AZ-101 and HLW98-86 for C-106/AY-102. The compositions of these two glasses are provided in Table 4.1. The two glasses had in general similar compositions except for two components that had the most noticeable difference: $\mathrm{ZrO}_{2}$ was higher in HLW98-77 for AZ-101 (3.8 wt\% compared to 0.26 wt\%) but MnO was higher in HLW98-86 glass for C-106/AY-102 (4 wt\% compared to $0.17 \mathrm{wt} \%$ ). These two glasses had similar viscosity at $1150^{\circ} \mathrm{C}$, 5.2 Pa·s for HLW98-77 and 4.4 Pa·s for HLW98-86.

Table 4.1. Composition of Glasses Formulated for Simulated AZ-101 and C-106/AY-102 Wastes Selected for LSM Tests (in mass fraction, from Matlack et al. 2004a and 2003b)

\begin{tabular}{|c|c|c|}
\hline Waste & AZ-101 & C-106/AY-102 \\
\hline Glass ID & HLW98-77 & HLW98-86 \\
\hline $\mathrm{Al}_{2} \mathrm{O}_{3}$ & 0.0519 & 0.0529 \\
\hline $\mathrm{As}_{2} \mathrm{O}_{5}$ & - & 0.0022 \\
\hline $\mathrm{B}_{2} \mathrm{O}_{3}$ & 0.1190 & 0.0939 \\
\hline $\mathrm{BaO}$ & 0.0002 & - \\
\hline $\mathrm{CaO}$ & 0.0028 & 0.0030 \\
\hline $\mathrm{CdO}$ & 0.0006 & - \\
\hline $\mathrm{Cl}$ & - & 0.0011 \\
\hline $\mathrm{Cr}_{2} \mathrm{O}_{3}$ & - & 0.0008 \\
\hline $\mathrm{Cs}_{2} \mathrm{O}$ & $<0.0001$ & 0.0005 \\
\hline $\mathrm{CuO}$ & 0.0003 & 0.0004 \\
\hline F & 0.0004 & - \\
\hline $\mathrm{Fe}_{2} \mathrm{O}_{3}$ & 0.1221 & 0.1258 \\
\hline $\mathrm{I}$ & 0.0010 & 0.0010 \\
\hline $\mathrm{K}_{2} \mathrm{O}$ & 0.0003 & - \\
\hline $\mathrm{La}_{2} \mathrm{O}_{3}$ & 0.0041 & 0.0024 \\
\hline $\mathrm{Li}_{2} \mathrm{O}$ & 0.0352 & 0.0301 \\
\hline $\mathrm{MgO}$ & 0.0011 & 0.0117 \\
\hline $\mathrm{MnO}$ & 0.0017 & 0.0400 \\
\hline $\mathrm{Na}_{2} \mathrm{O}$ & 0.1165 & 0.1183 \\
\hline $\mathrm{Nd}_{2} \mathrm{O}_{3}$ & 0.0031 & 0.0015 \\
\hline $\mathrm{NiO}$ & 0.0061 & 0.0017 \\
\hline $\mathrm{P}_{2} \mathrm{O}_{5}$ & - & 0.0009 \\
\hline $\mathrm{PbO}$ & 0.0003 & 0.0014 \\
\hline $\mathrm{SO}_{3}$ & 0.0007 & - \\
\hline $\mathrm{Sb}_{2} \mathrm{O}_{3}$ & - & 0.0025 \\
\hline $\mathrm{SeO}_{2}$ & - & 0.0037 \\
\hline $\mathrm{SiO}_{2}$ & 0.4740 & 0.4704 \\
\hline $\mathrm{SrO}$ & 0.0003 & 0.0092 \\
\hline $\mathrm{TiO}_{2}$ & - & 0.0014 \\
\hline $\mathrm{ZnO}$ & 0.0201 & 0.0207 \\
\hline $\mathrm{ZrO}_{2}$ & 0.0380 & 0.0026 \\
\hline
\end{tabular}


The composition of HLW98-77 glass feed with AZ-101 is provided in Table 4.2 and that of HLW98-86 glass feed for C-106/AY-102 is in Table 4.3. These data were obtained by modifying the recipes given in Matlack et al. (2004a, 2003b) based on specific materials available at PNNL. These recipes are for the feeds with a glass yield of $500 \mathrm{~g} / \mathrm{L}$.

Table 4.2. Composition of AZ-101 Waste Glass Feeds Selected for LSM Tests (in g per kg glass, at $500 \mathrm{~g} / \mathrm{L}$ for HLW98-77 glass [modified ${ }^{(\mathrm{a})}$ from Matlack et al. 2004a])

\begin{tabular}{|c|c|c|c|}
\hline Materials (for Simulated Waste) & Target, $\mathrm{g}$ & Materials (for additives) & Target, $\mathrm{g}$ \\
\hline $\mathrm{Al}(\mathrm{OH})_{3}$ & 79.75 & & \\
\hline $\mathrm{H}_{3} \mathrm{BO}_{3}$ & 2.61 & $\mathrm{Na}_{2} \mathrm{~B}_{4} \mathrm{O}_{7} \cdot 10 \mathrm{H}_{2} \mathrm{O}$ & 321.89 \\
\hline $\mathrm{Ba}(\mathrm{OH})_{2} \cdot 8 \mathrm{H}_{2} \mathrm{O}$ & 0.371 & & \\
\hline $\mathrm{Ca}(\mathrm{OH})_{2}$ & 3.75 & & \\
\hline $\mathrm{CdO}$ & 0.638 & & \\
\hline $\mathrm{CsOH} \cdot \mathrm{H}_{2} \mathrm{O}(90 \%)$ & 0.033 & & \\
\hline $\mathrm{CuO}$ & 0.304 & & \\
\hline $\mathrm{NaF}$ & 0.846 & & \\
\hline $\mathrm{Fe}(\mathrm{OH})_{3}(13 \%$ slurry $)$ & 1257.45 & & \\
\hline $\mathrm{NaI}$ & 1.19 & & \\
\hline $\mathrm{KNO}_{3}$ & 0.710 & & \\
\hline $\mathrm{La}(\mathrm{OH})_{3}$ & 4.74 & & \\
\hline $\mathrm{Li}_{2} \mathrm{CO}_{3}$ & 0.505 & $\mathrm{Li}_{2} \mathrm{CO}_{3}$ & 87.42 \\
\hline $\mathrm{Mg}(\mathrm{OH})_{2}$ & 1.550 & & \\
\hline $\mathrm{MnO}_{2}$ & 2.08 & & \\
\hline $\mathrm{NaOH}$ & 8.92 & $\mathrm{Na}_{2} \mathrm{CO}_{3}$ & 91.03 \\
\hline $\mathrm{Nd}_{2} \mathrm{O}_{3}$ & 3.08 & & \\
\hline $\mathrm{Ni}(\mathrm{OH})_{2}(62.2 \% \mathrm{Ni})$ & 7.75 & & \\
\hline $\mathrm{PbO}$ & 0.329 & & \\
\hline $\mathrm{SiO}_{2}()$ & 4.05 & $\mathrm{SiO}_{2}$ & 470.94 \\
\hline $\mathrm{Na}_{2} \mathrm{SO}_{4}$ & 1.35 & & \\
\hline $\mathrm{Sr}(\mathrm{OH})_{2} \cdot 8 \mathrm{H}_{2} \mathrm{O}$ & 0.886 & & \\
\hline $\mathrm{ZnO}$ & 0.152 & $\mathrm{ZnO}$ & 20.00 \\
\hline $\mathrm{Zr}(\mathrm{OH})_{4} \cdot \mathrm{xH}_{2} \mathrm{O}(\sim 38 \% \mathrm{Zr})$ & 73.51 & & \\
\hline $\mathrm{NaNO}_{2}$ & 1.60 & & \\
\hline $\mathrm{NaNO}_{3}$ & 7.19 & & \\
\hline $\mathrm{H}_{2} \mathrm{C}_{2} \mathrm{O}_{4} \cdot 2 \mathrm{H}_{2} \mathrm{O}$ & 1.23 & & \\
\hline Subtotal (no water) & 1466.58 & & \\
\hline Water (estimated) ${ }^{(\mathrm{b})}$ & 286.50 & Subtotal & 991.29 \\
\hline \multirow{3}{*}{\multicolumn{2}{|c|}{$\begin{array}{l}(\mathrm{a}) \mathrm{La}(\mathrm{OH})_{3} \text { is used instead of } \mathrm{La}(\mathrm{OH})_{3} \cdot 3 \mathrm{H}_{2} \mathrm{O} \text {. } \\
\text { (b) Water is estimated and for information only. } \\
\text { Shaded empty cells represent no data. }\end{array}$}} & Total (no water) & 2457.87 \\
\hline & & Total (estimated with water) & 2744.37 \\
\hline & & Target Volume of Slurry Feed, mL & 2000 \\
\hline
\end{tabular}


Table 4.3. Composition of C-106/AY-102 Waste Glass Feeds Selected for LSM Tests (in g per kg glass, at $500 \mathrm{~g} / \mathrm{L}$, for HLW98-86 glass, modified ${ }^{(\mathrm{a})}$ from Matlack et al. 2003b)

\begin{tabular}{|c|c|c|c|}
\hline Materials (for simulated waste) & Target, g & Materials (for additives) & Target, $\mathbf{g}$ \\
\hline $\mathrm{Al}(\mathrm{OH})_{3}$ & 54.43 & $\mathrm{Al}_{2} \mathrm{O}_{3}$ & 17.51 \\
\hline $\mathrm{As}_{2} \mathrm{O}_{3}$ & 1.92 & & \\
\hline $\mathrm{H}_{3} \mathrm{BO}_{3}$ & 2.42 & $\mathrm{Na}_{2} \mathrm{~B}_{4} \mathrm{O}_{7} \cdot 10 \mathrm{H}_{2} \mathrm{O}$ & 253.40 \\
\hline $\mathrm{CaCO}_{3}$ & 5.43 & & \\
\hline $\mathrm{NaCl}$ & 1.78 & & \\
\hline $\mathrm{Cr}_{2} \mathrm{O}_{3}$ & 0.781 & & \\
\hline $\mathrm{CsOH} \cdot \mathrm{H}_{2} \mathrm{O}(90 \%)$ & 0.661 & & \\
\hline $\mathrm{CuO}$ & 0.445 & & \\
\hline $\mathrm{Fe}(\mathrm{OH})_{3}(\sim 13 \%$ slurry $)$ & 1284.61 & & \\
\hline $\mathrm{NaI}$ & 1.18 & & \\
\hline $\mathrm{La}(\mathrm{OH})_{3}$ & 2.82 & & \\
\hline $\mathrm{Li}_{2} \mathrm{CO}_{3}$ & 0.139 & $\mathrm{Li}_{2} \mathrm{CO}_{3}$ & 74.93 \\
\hline $\mathrm{Mg}(\mathrm{OH})_{2}$ & 17.07 & & \\
\hline $\mathrm{MnO}_{2}$ & 49.15 & & \\
\hline $\mathrm{Na}_{2} \mathrm{CO}_{3}$ & 6.14 & $\mathrm{Na}_{2} \mathrm{CO}_{3}$ & 123.21 \\
\hline $\mathrm{Nd}_{2} \mathrm{O}_{3}$ & 1.50 & & \\
\hline $\mathrm{Ni}(\mathrm{OH})_{2}(62.2 \% \mathrm{Ni})$ & 2.17 & & \\
\hline $\mathrm{FePO}_{4} \cdot \mathrm{xH}_{2} \mathrm{O}(80 \%)$ & 2.52 & & \\
\hline $\mathrm{PbO}$ & 1.44 & & \\
\hline $\mathrm{Sb}_{2} \mathrm{O}_{3}$ & 2.56 & & \\
\hline $\mathrm{SeO}_{2}$ & 3.74 & & \\
\hline $\mathrm{SiO}_{2}$ & 20.44 & $\mathrm{SiO}_{2}$ & 450.90 \\
\hline $\mathrm{SrCO}_{3}$ & 13.22 & & \\
\hline $\mathrm{TiO}_{2}$ & 1.42 & & \\
\hline $\mathrm{ZnO}$ & 0.694 & $\mathrm{ZnO}$ & 20.00 \\
\hline $\mathrm{Zr}(\mathrm{OH})_{4} \cdot \mathrm{xH}_{2} \mathrm{O}(\sim 38 \% \mathrm{Zr})$ & 4.99 & & \\
\hline $\mathrm{NaNO}_{2}$ & 0.051 & & \\
\hline $\mathrm{NaNO}_{3}$ & 3.00 & & \\
\hline $\mathrm{H}_{2} \mathrm{C}_{2} \mathrm{O}_{4} \cdot 2 \mathrm{H}_{2} \mathrm{O}$ & 0.379 & & \\
\hline Subtotal (no water) & 1487.10 & & \\
\hline Water (estimated) ${ }^{(\mathrm{b})}$ & 233.500 & Subtotal & 939.96 \\
\hline \multirow{3}{*}{\multicolumn{2}{|c|}{$\begin{array}{l}\text { (a) } \mathrm{La}(\mathrm{OH})_{3} \text { is used instead of } \mathrm{La}(\mathrm{OH})_{3} \cdot 3 \mathrm{H}_{2} \mathrm{O} . \\
\text { (b) Water is estimated and for information only. } \\
\text { Shaded empty cells represent no data. }\end{array}$}} & Total (no water) & 2427.05 \\
\hline & & Total (estimated with water) & 2660.55 \\
\hline & & Target Volume of Slurry Feed, mL & 2000 \\
\hline
\end{tabular}





\subsection{Laboratory-Scale Melter Tests}

\subsection{Test Procedure}

The $500 \mathrm{~g} / \mathrm{L}$ feed was prepared by mixing all ingredients given in Table 4.2 or Table 4.3 in a stainless-steel container with a stainless-steel bar for $1 \mathrm{~h}$. The feeds with 300 or $400 \mathrm{~g} / \mathrm{L}$ were prepared by adding an appropriate amount of water to the $500 \mathrm{~g} / \mathrm{L}$ feed. For the preparation of AZ-101 feed, too much water was added accidently and resulted in $479 \mathrm{~g} / \mathrm{L}$ feed instead of the targeted $500 \mathrm{~g} / \mathrm{L}$. Three LSM tests were performed with AZ-101 feeds at 300, 400, and $479 \mathrm{~g} / \mathrm{L}$ and one test was performed with C-106/AY-102 feed at $400 \mathrm{~g} / \mathrm{L}$. Density of the feed for each LSM test was measured using a graduated cylinder and summarized in Table 5.1.

Table 5.1. Measured Density of LSM Feeds

\begin{tabular}{|c|c|}
\hline Feed & Density, $\mathbf{g} / \mathbf{c m}^{\mathbf{3}}$ \\
\hline AZ-101, 300 g/L & 1.178 \\
\hline AZ-101, 400 g/L & 1.274 \\
\hline AZ-101, 479 g/L & 1.396 \\
\hline C-106/AY-102, 400 g/L & 1.281 \\
\hline
\end{tabular}

For each test, the glass cullet of the same glass composition as the test melter feed was loaded into the quart crucible for the amount to fill the crucible roughly $2 \mathrm{~cm}$ height when melted at $\sim 1150^{\circ} \mathrm{C}$ and heated to a predetermined temperature. Feed was introduced into the crucible via a peristaltic pump that was calibrated for the feeding rate before each test from a beaker of the slurry mixture that was stirred on a stir plate throughout the test period. Table 5.2 summarizes the calibrated feeding rates for the slurry feeds used in this study.

Table 5.2. Calibrated Feeding Rates for LSM Feeds

\begin{tabular}{|c|c|c|c|c|}
\hline \multirow{2}{*}{$\begin{array}{c}\text { Flow Meter } \\
\text { Reading }\end{array}$} & $\begin{array}{c}\text { AZ-101 } \\
\mathbf{3 0 0} \mathbf{g} / \mathbf{L}\end{array}$ & \multicolumn{4}{|c|}{$\begin{array}{c}\text { AZ-101 } \\
\mathbf{4 0 0} \mathbf{g} / \mathbf{L}\end{array}$} & $\begin{array}{c}\text { AZ-101 } \\
\mathbf{4 7 9} \mathbf{g} / \mathbf{L}\end{array}$ & $\begin{array}{c}\text { C-106/AY-102 } \\
\mathbf{4 0 0} \mathbf{~ g / L}\end{array}$ \\
\cline { 2 - 5 } & \multicolumn{4}{|c|}{ Feeding Rate, $\mathbf{~ m L / m i n}$} \\
\hline 3 & 3.4 & 3.2 & 3.4 & 3.4 \\
\hline 3.5 & $\mathrm{NM}$ & $\mathrm{NM}$ & 3.7 & $\mathrm{NM}$ \\
\hline 4 & 4.5 & 4.3 & 4.2 & 4.1 \\
\hline 5 & 5.4 & 5.2 & $\mathrm{NM}$ & 5.3 \\
\hline
\end{tabular}

NM: Not measured.

\subsection{Test Results with Initial Setup}

As mentioned in Section 3.0, the preliminary tests were not successful to obtain the steady state melting rate that can be used to compare with the melting rate data from scaled-melter tests. Figure 5.1 shows a cold-cap sample taken from the test with AZ-101 feed with $300 \mathrm{~g} / \mathrm{L}$ glass yield displaying an 
extreme example of the cold cap with large cavities formed between the unreacted feed and glass. Because of the blocked view discussed earlier, it was difficult to make a good estimation of the cold-cap coverage, which resulted in feeding too fast for some tests without noticing the formation of thick cold-cap with large cavities illustrated in Figure 5.1.

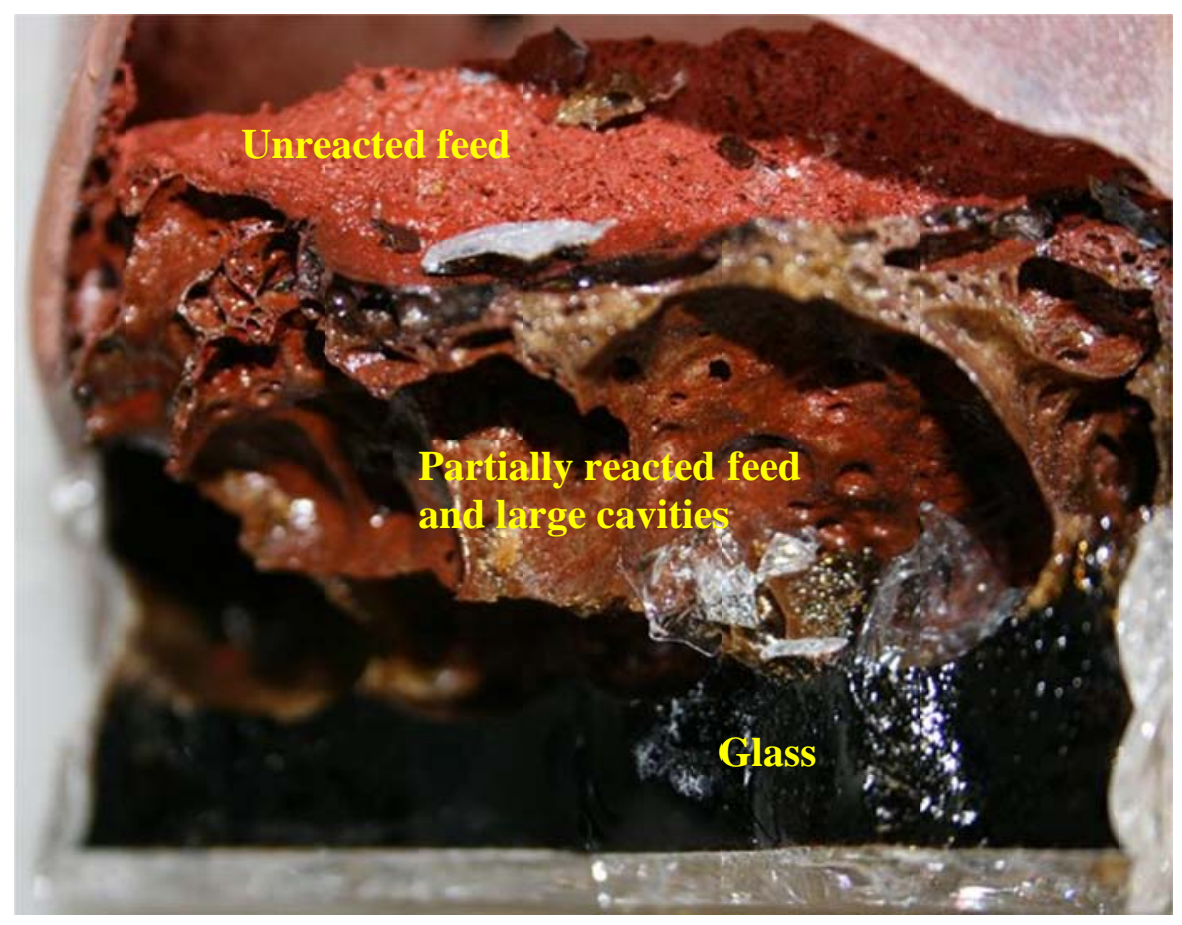

Figure 5.1. Cold-Cap Sample Taken from LSM Test with AZ-101 feed at $300 \mathrm{~g} / \mathrm{L}$

Figure 5.2 shows a cold sample taken from another test with AZ-101 feed with 300 g/L glass yield, which was used to examine the cold-cap structure by scanning electron microscopy (SEM). The cold-cap photo in Figure 5.2(a) shows the areas that SEM micrographs given in Figure 5.2(b) and Figure 5.2(c) were taken. Figure 5.2(b) and Figure 5.2(c) show distinct features of partially reacted feed with open pores and of foam layer with closed gas bubbles. The areas Figure 5.2(d) confirms the material marked as "Partially reacted feed" in Figure 5.2(b) contain various unreacted feed materials, including quartz $\left(\mathrm{SiO}_{2}\right)$. It was found from evaluation of this sample and other similar cold-cap samples that the partially reacted feed, foam, and glass are not present in distinct layers, which suggests they become intermixed within the cold cap. Further studies are needed to better understand the proposed cold-cap behavior, which will help to build the cold-cap model structure more realistically than that discussed in the melting rate model report (Pokorny and Hrma 2010). 


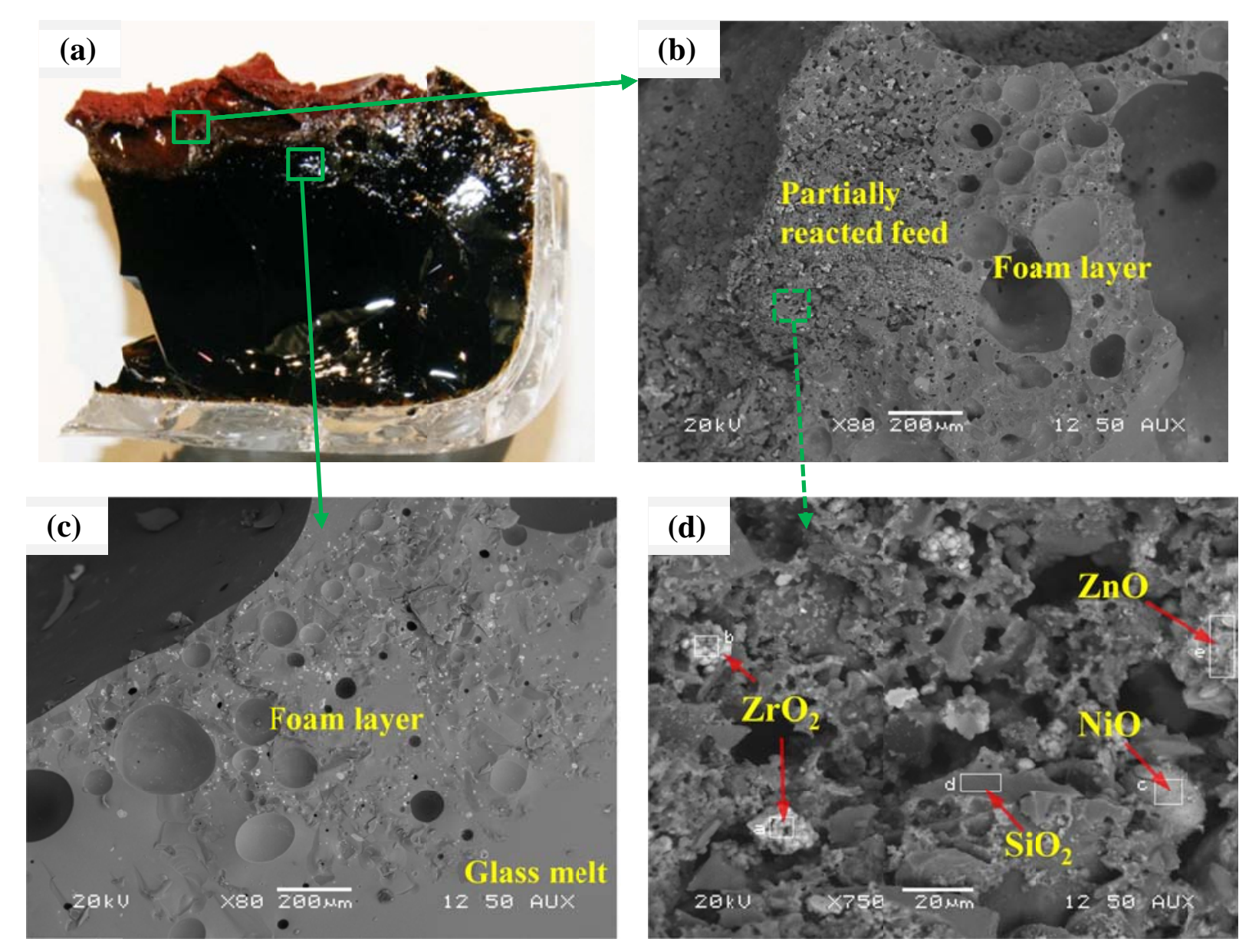

Figure 5.2. Example of Cold-Cap Sample Analyses: (a) picture of glass-cold cap sample from LSM test with AZ-101 feed at $300 \mathrm{~g} / \mathrm{L}$; (b) and (c) SEM micrographs of the areas indicated in (a); (d) high magnification SEM micrograph of area indicated in (b) with phases identified

\subsection{Test Results with Improved Setup}

Figure 5.3 show a sequence of top-view images that illustrate the conversion of the AZ-101 glass during furnace ramp heating to a preset temperature before adding the slurry feed. Figure 5.4 shows the initial stage of the cold-cap formation for tests with $300 \mathrm{~g} / \mathrm{L} \mathrm{AZ-101}$ glass feed. The feed nozzle and thermocouple are also shown in this picture.

Figure 5.5 shows the example pictures of steady-state cold cap formed in three tests with AZ-101 glass feeds. The relatively large bubbles bursting at the melt surface between the cold cap and crucible wall were seen (see brighter circles around the cold cap formed by hotter glass that are being pushed to the colder surface). It was found that to achieve a steady-state cold cap melting a certain minimum distance needs to be maintained between the cold-cap boundary and crucible wall so that the bubbles can rise to the melt surface and burst freely without causing bridging. Figure 5.6 shows the pictures of cold-cap glass samples after the LSM tests. As expected, the cold-cap thickness after cooling was much smaller compared to those from the initial tests discussed in Section 5.2. 

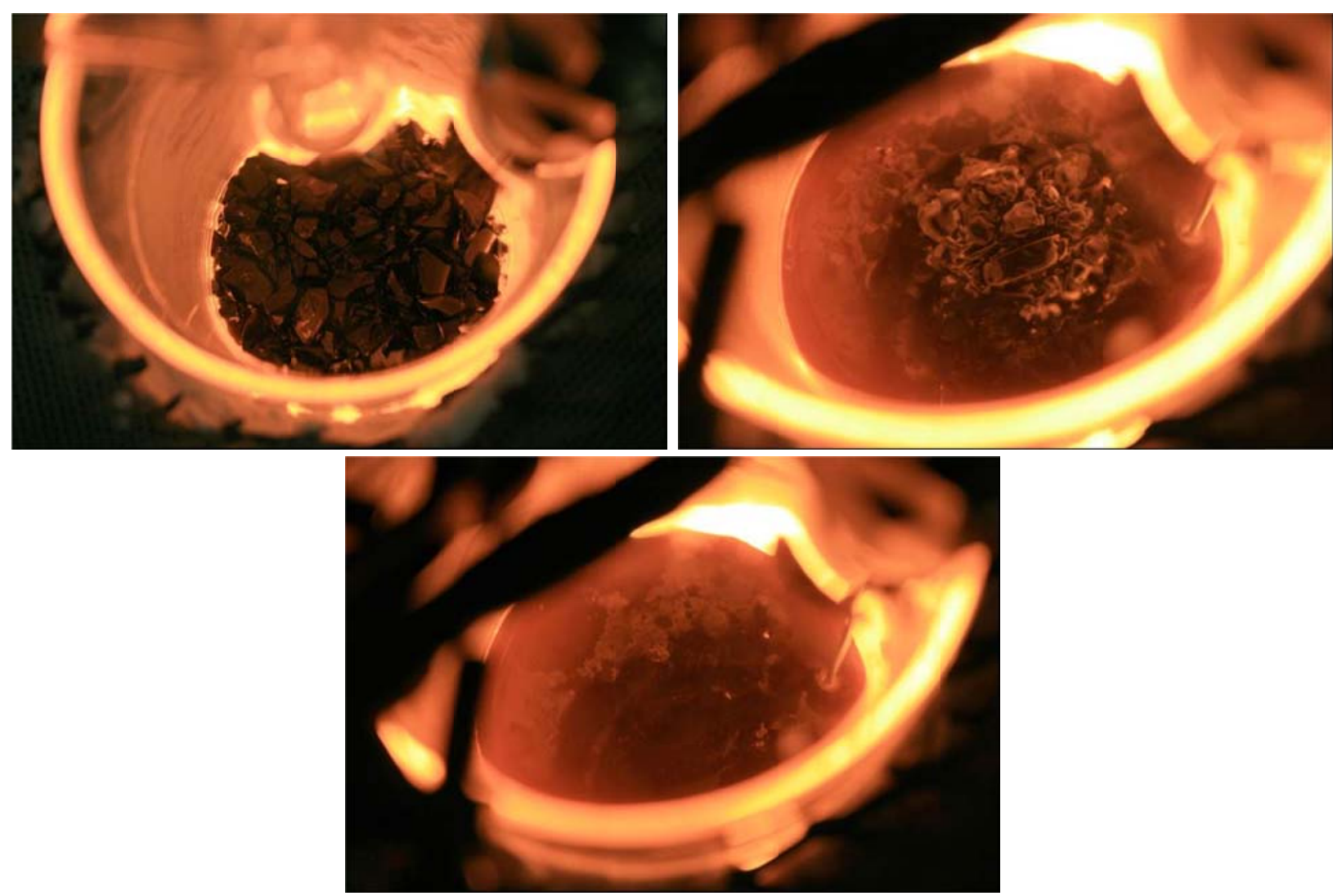

Figure 5.3. Pictures Showing the Sequence of Melting the AZ-101 Glass Cullet during Ramp Heating Before Adding the Slurry Feed

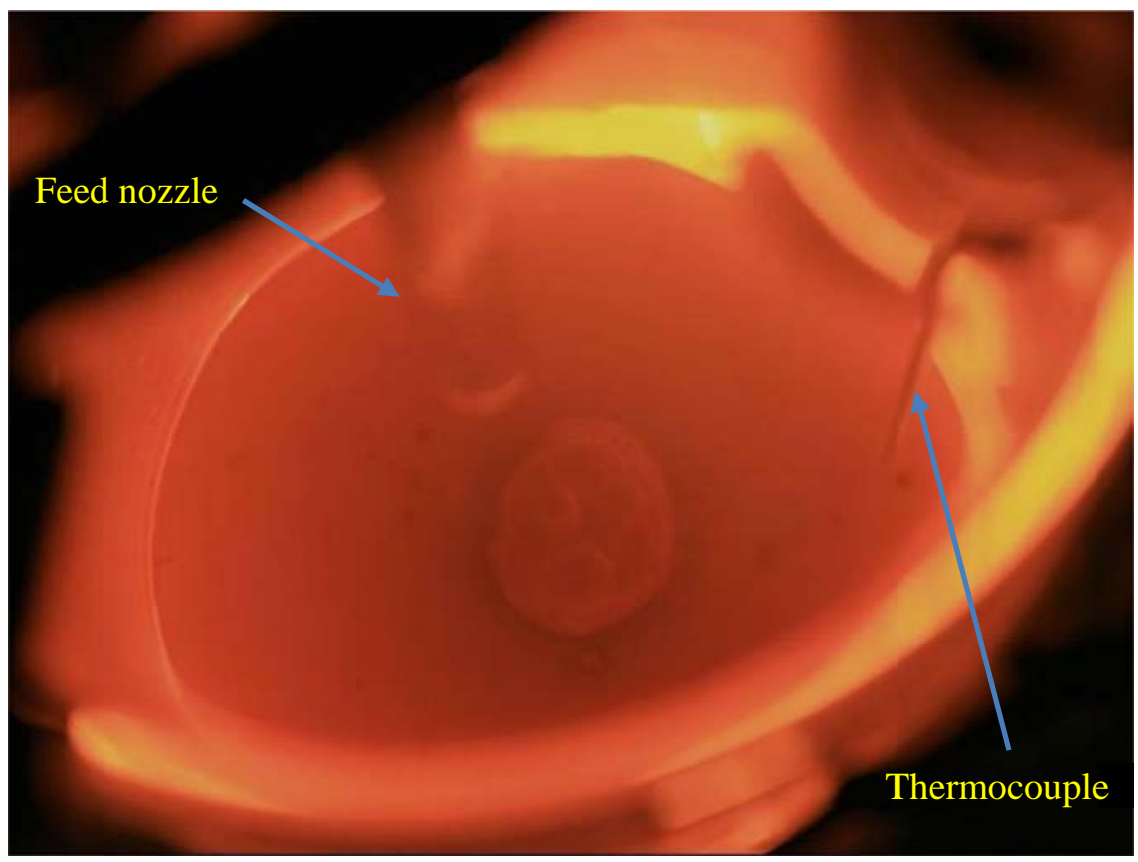

Figure 5.4. Picture Showing the Initial Stage of Cold-Cap Formation After Adding the Slurry Feed (300 g/L AZ-101 glass feed) 


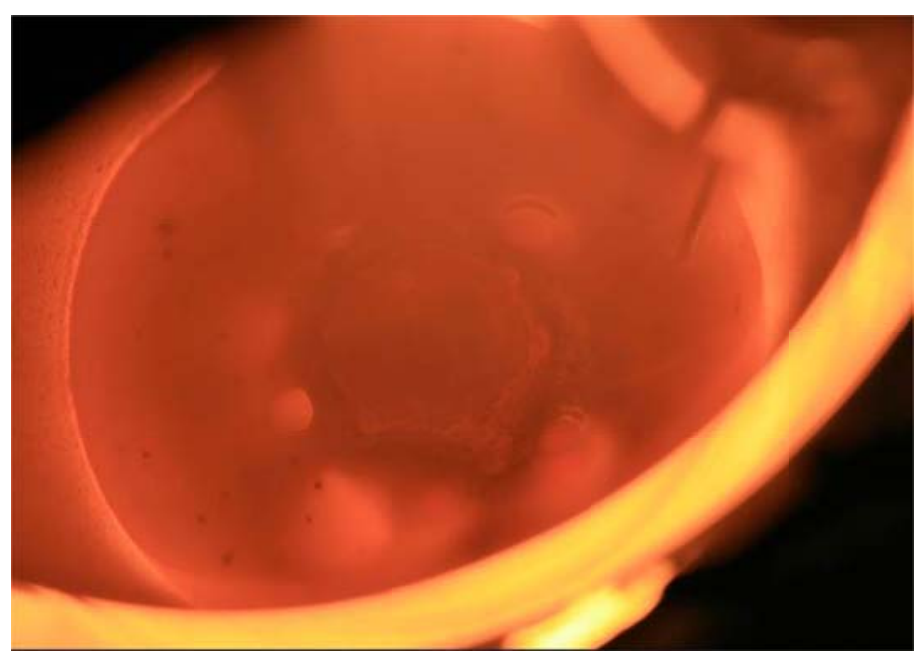

300 g/L AZ-101

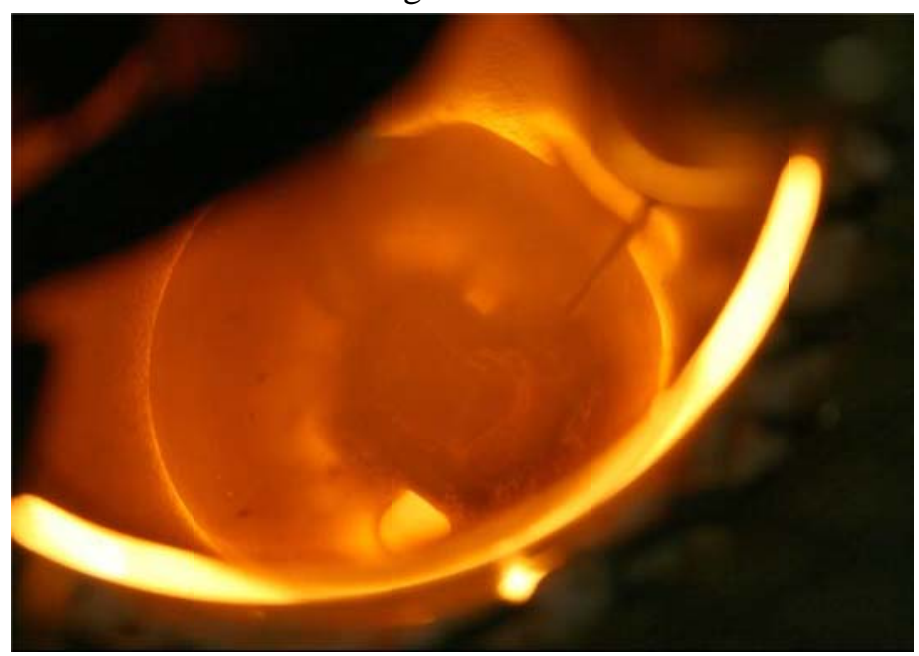

400 g/L AZ-101

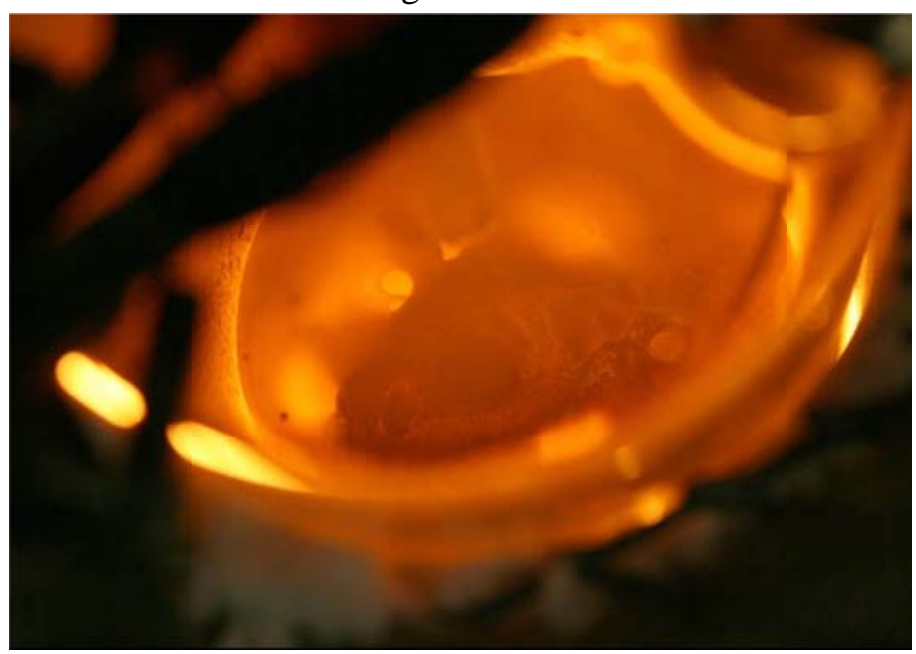

479 g/L AZ-101

Figure 5.5. Pictures Showing the Steady State Cold-Cap with Large Bubbles Bursting Through Glass Melt Around the Cold Cap 


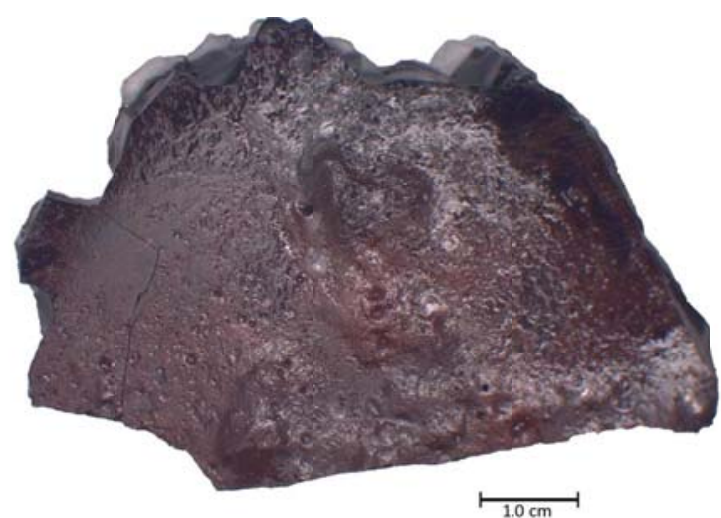

$300 \mathrm{~g} / \mathrm{L}$ AZ-101
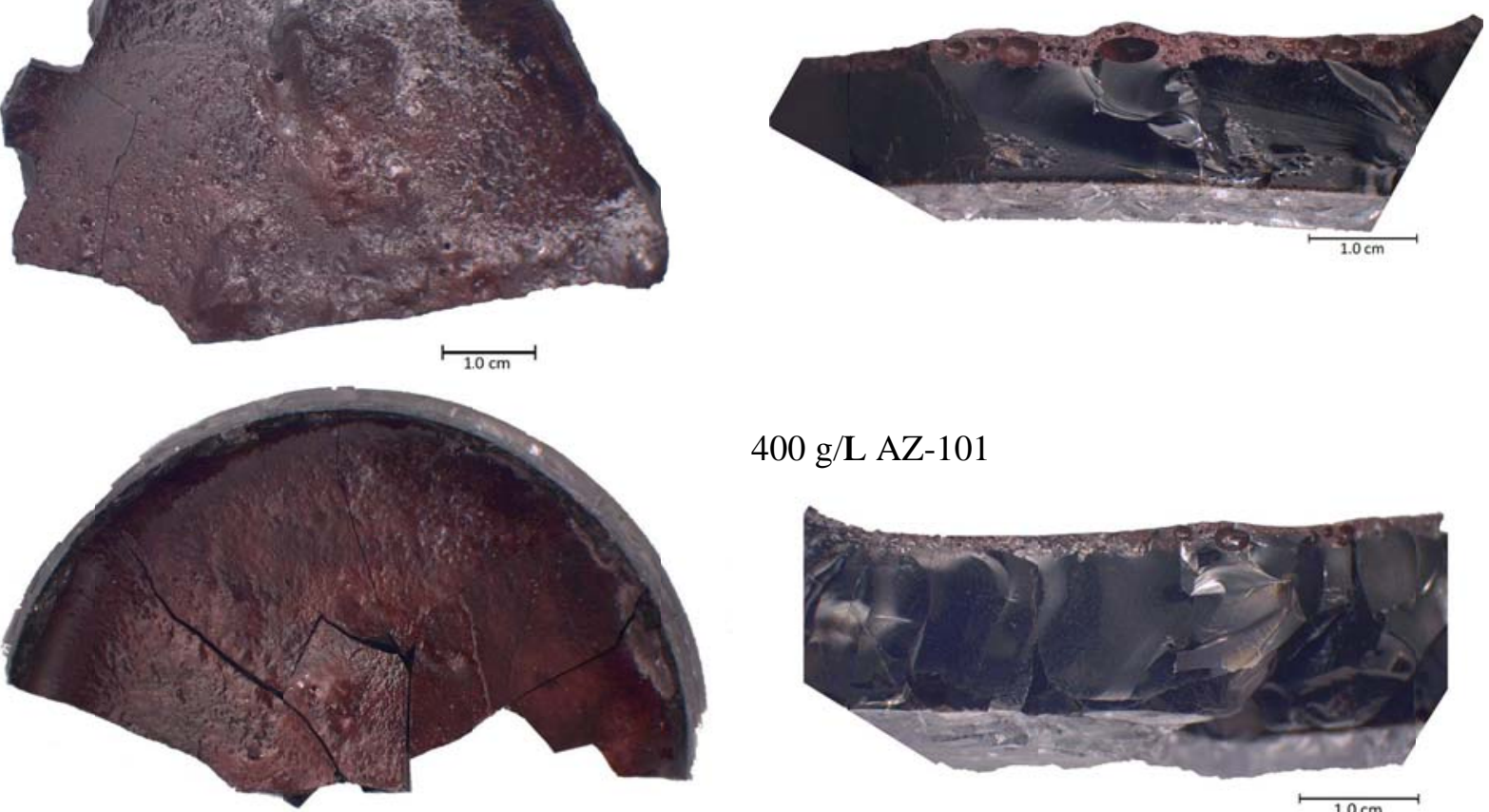

400 g/L AZ-101
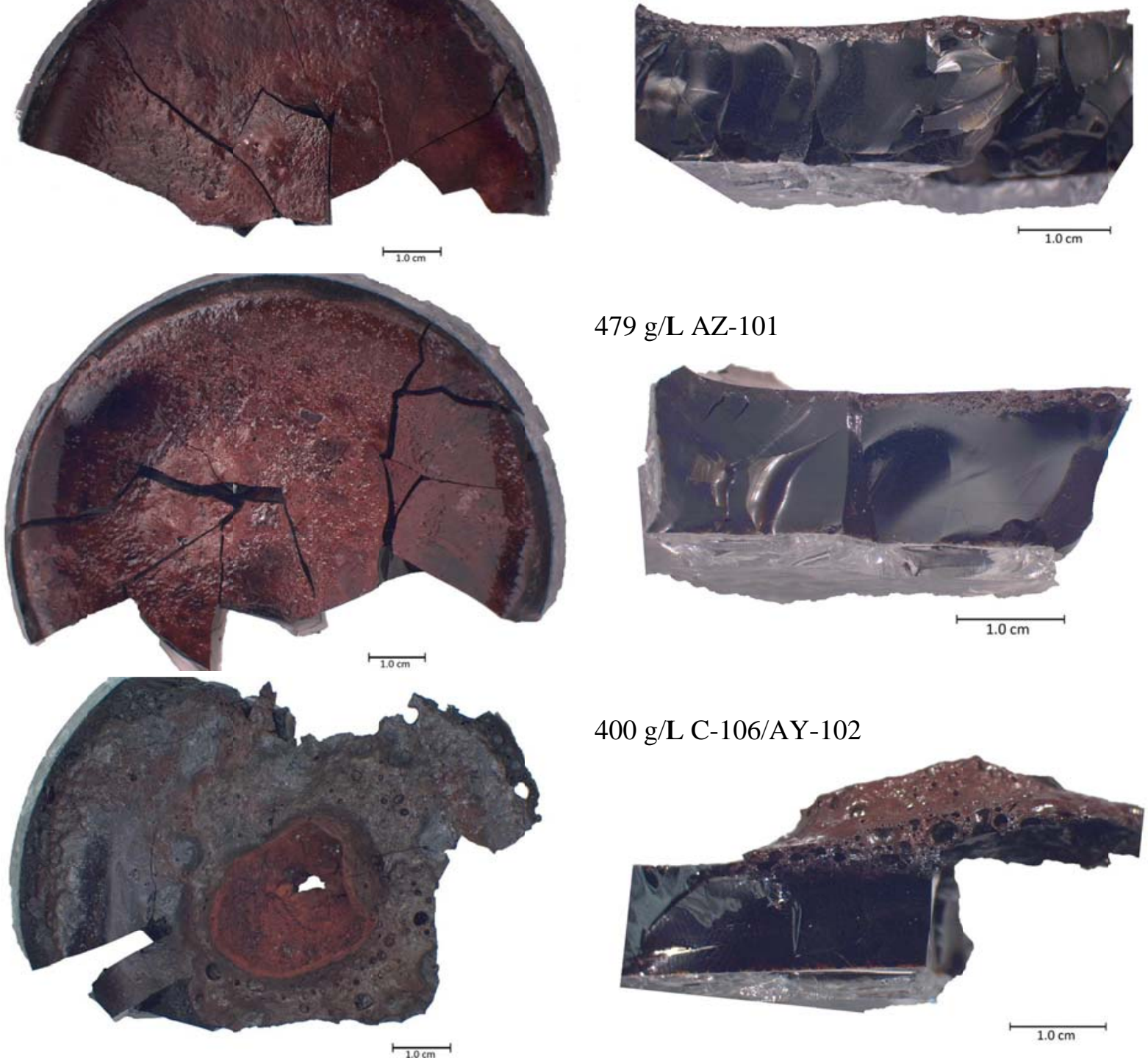

Figure 5.6. Pictures of Glass Samples with Quenched Cold-Caps on Top After LSM Tests (left side images are top-view, right side-images are side-view) 
The melting rate, given as glass production rate per unit melt surface area, was calculated from the slurry feed rate used when the steady-state cold cap melting was achieved. The glass production rate in $\mathrm{kg} /\left(\mathrm{m}^{2} \mathrm{~d}\right)$ is obtained by multiplying the steady-state feed rate $(\mathrm{L} / \mathrm{d})$ by the glass yield (kg glass/L feed) and then divided by the inner cross section area of the quartz crucible $\left(0.00732 \mathrm{~m}^{2}\right)$. Table 5.3 summarizes the steady-state feed rates and resulting melting rates.

Table 5.3. Steady-State Feed Rate and Melting Rate from LSM Tests

\begin{tabular}{|c|c|c|}
\hline Melter Feed & $\begin{array}{l}\text { Steady-State Feed } \\
\text { Rate, L/min }\end{array}$ & 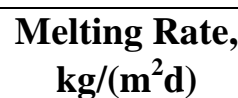 \\
\hline AZ-101 $300 \mathrm{~g} / \mathrm{L}$ & 4.43 & 262 \\
\hline AZ-101 $400 \mathrm{~g} / \mathrm{L}$ & 4.23 & 333 \\
\hline AZ-101 $479 \mathrm{~g} / \mathrm{L}$ & 4.17 & 393 \\
\hline C-106/AY-102 400 g/L & 3.32 & 261 \\
\hline
\end{tabular}

Figure 5.7 shows the measured melting rates from LSM tests with three AZ-101 glass feeds and one C-106/AY-102 glass feed tested by LSM in this study compared with the predicted melting rates for DM1200 and DM100 calculated using Equations (1) and (2) in Section 2.0.

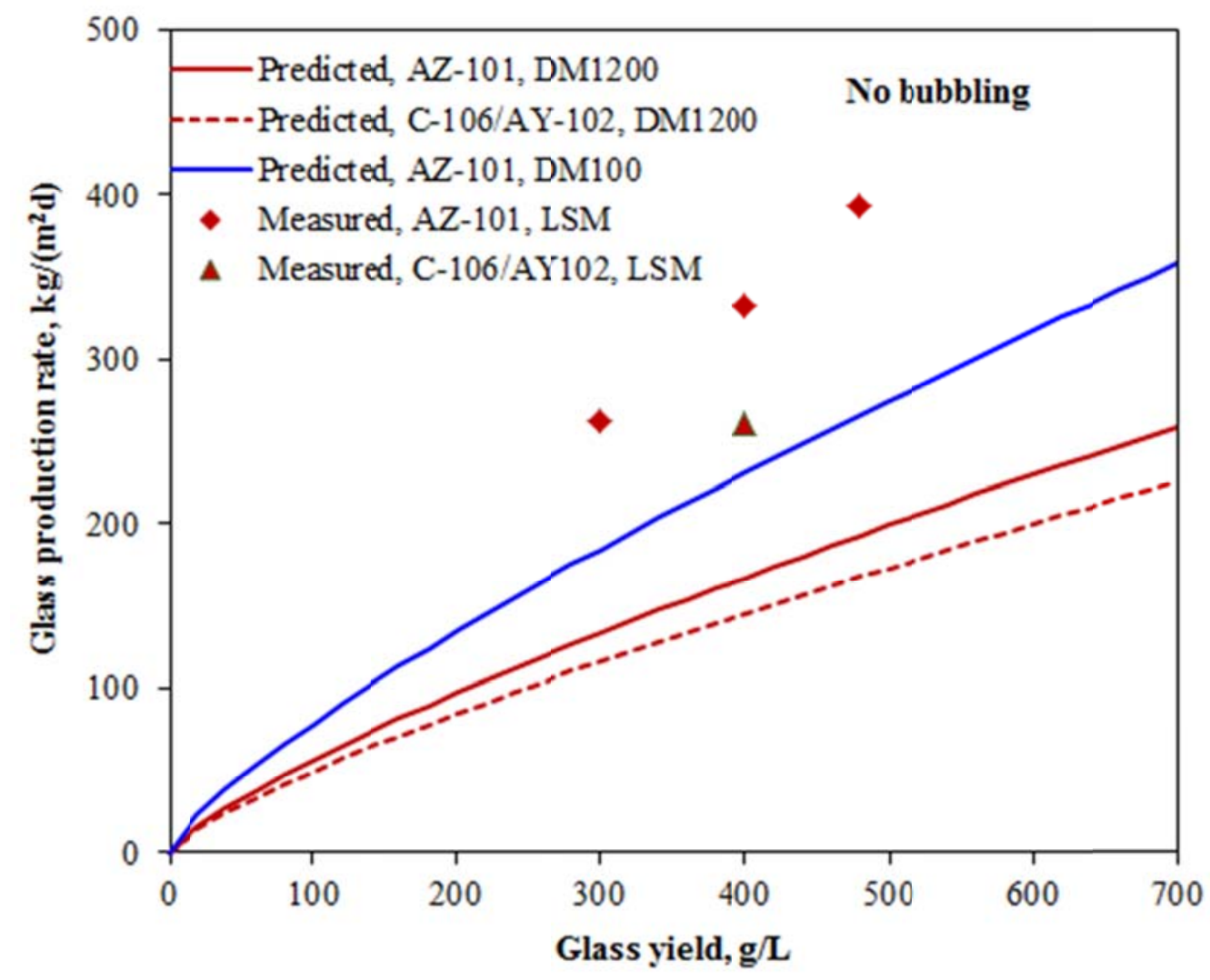

Figure 5.7. Melting Rates Measured from LSM Tests Compared with Predicted Melting Rates for DM1200 and DM100 Calculated by Equations (1) and (2) 
Figure 5.7 shows that the melting rates of AZ-101 feeds increase with increasing glass yield as expected and as predicted from the scaled-melter test data. Figure 5.7 also shows the AZ-101 feeds process faster than the C-106/AY-102 feeds, which corresponds with the scaled-melter test data.

Comparison between the results from the LSM and scaled-melter tests is limited to relative evaluation only because of major differences in their construction and operation conditions. However, to obtain a rough estimate on the possible effect of melter surface area on the melting rate, the melting rate data from DM1200 (Table 2.1), DM100 (Table 2.2), and LSM (Table 5.3) tests with AZ-101 feeds were fitted to Equation (3):

$$
r_{G}=\left(1+c_{B} r_{B}^{m}\right) c_{G} y_{G}^{n} A_{S}^{p}
$$

where $\quad r_{G}=$ glass production rate per unit melter surface area $\left[\mathrm{kg} /\left(\mathrm{m}^{2} \mathrm{~d}\right)\right]$

$r_{B}=$ bubbling rate per unit melter surface area $\left[\mathrm{L} /\left(\mathrm{m}^{2} \mathrm{~min}\right)\right]$

$y_{G}=$ glass yield per unit volume of slurry feed (g(glass) $/ \mathrm{L}_{\text {(feed) }}$ )

$A_{S}=$ melter surface area $\left(\mathrm{m}^{2}\right)$

$c_{B}$ and $c_{G}=$ coefficients dependent on melter feed

$m, n$ and $p=$ coefficients independent of melter feed

Table 5.4 summarizes the results of two regression options. The Option 1 used the $m, n, c_{B}$ and $c_{G}$ values given in Table 2.3 and obtained the $p$ value from least-square regression while the Option 2 calculated all five coefficients from regression. Table 5.4 shows that the two regression options make little difference in the model coefficients, especially for $m, n$, and $p$, and $R^{2}$ values. Figure 5.9 is a plot of predicted versus measured production rate and Figure 5.10 shows predicted effects of melter surface area on the calculated glass production rate, based on the Option 1 regression. As mentioned earlier, Figure 5.10 illustrates a potential trend but is not for quantitative evaluation because of major differences in melter construction and operation conditions between the LSM and scaled melters.

Table 5.4. Model Coefficients for Glass Production Rate from DM1000/DM1200, DM100, and LSM Tests with AZ-101 Feeds

\begin{tabular}{|c|c|c|}
\hline Coefficient & Option 1 $^{(\mathbf{1})}$ & Option 2 $^{(\mathbf{2})}$ \\
\hline$m$ & 0.70 & 0.70 \\
\hline$n$ & 0.78 & 0.78 \\
\hline$p$ & -0.14 & -0.13 \\
\hline$C_{B}$ & 0.21 & 0.18 \\
\hline$C_{G}$ & 1.54 & 1.83 \\
\hline$R^{2}$ & 0.947 & 0.952 \\
\hline $\begin{array}{l}{ }^{(1)} \text { Same } m, n, c_{B} \text { and } c_{G} \text { values as in Table 2.3 were used } \\
\text { and only } p \text { was obtained from regression } \\
{ }^{(2)} \text { All five coefficients were obtained from regression }\end{array}$ \\
\hline
\end{tabular}




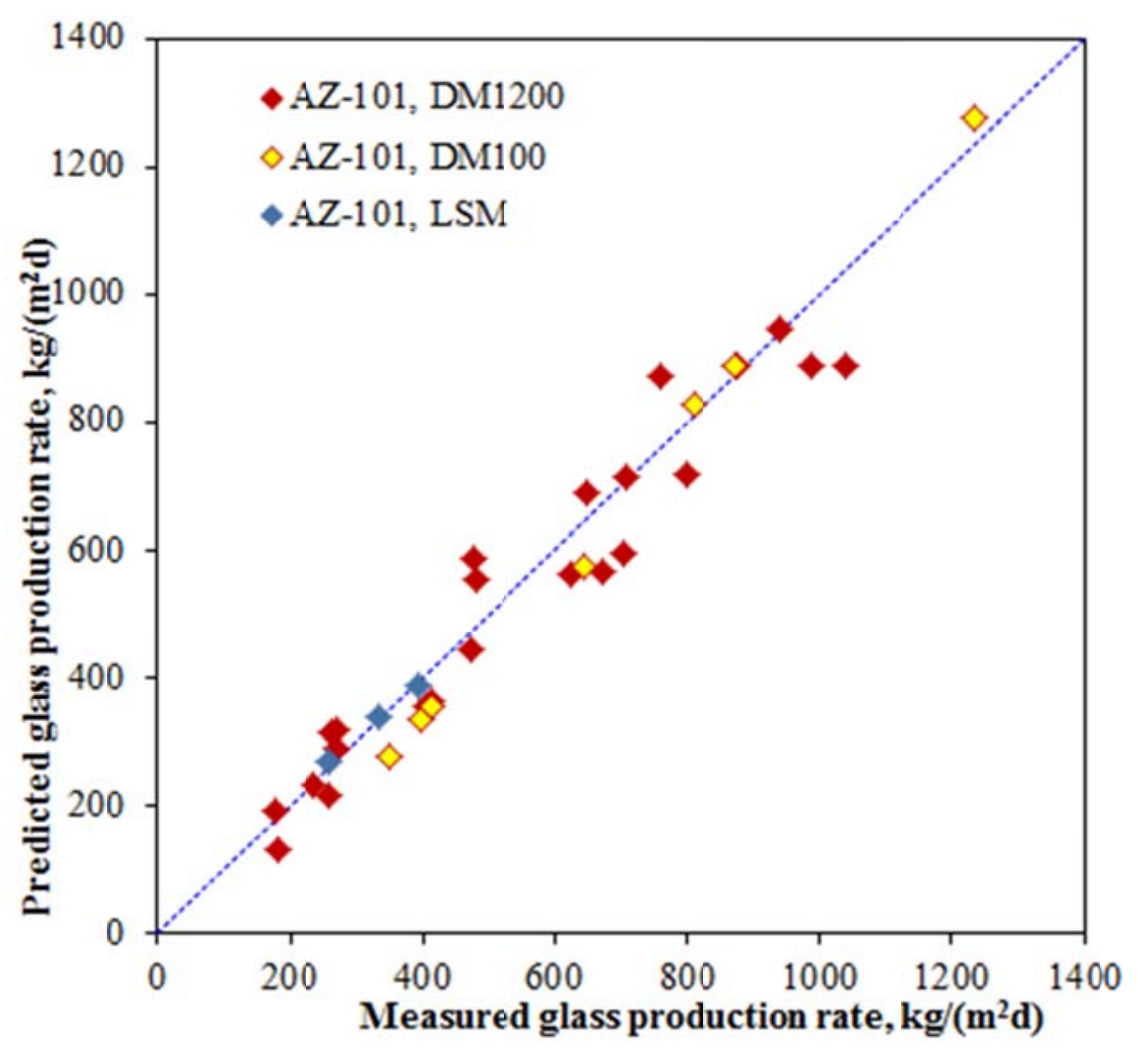

Figure 5.8. Predicted Versus Measured Glass Production Rate for Simulated AZ-101 Melter Feeds

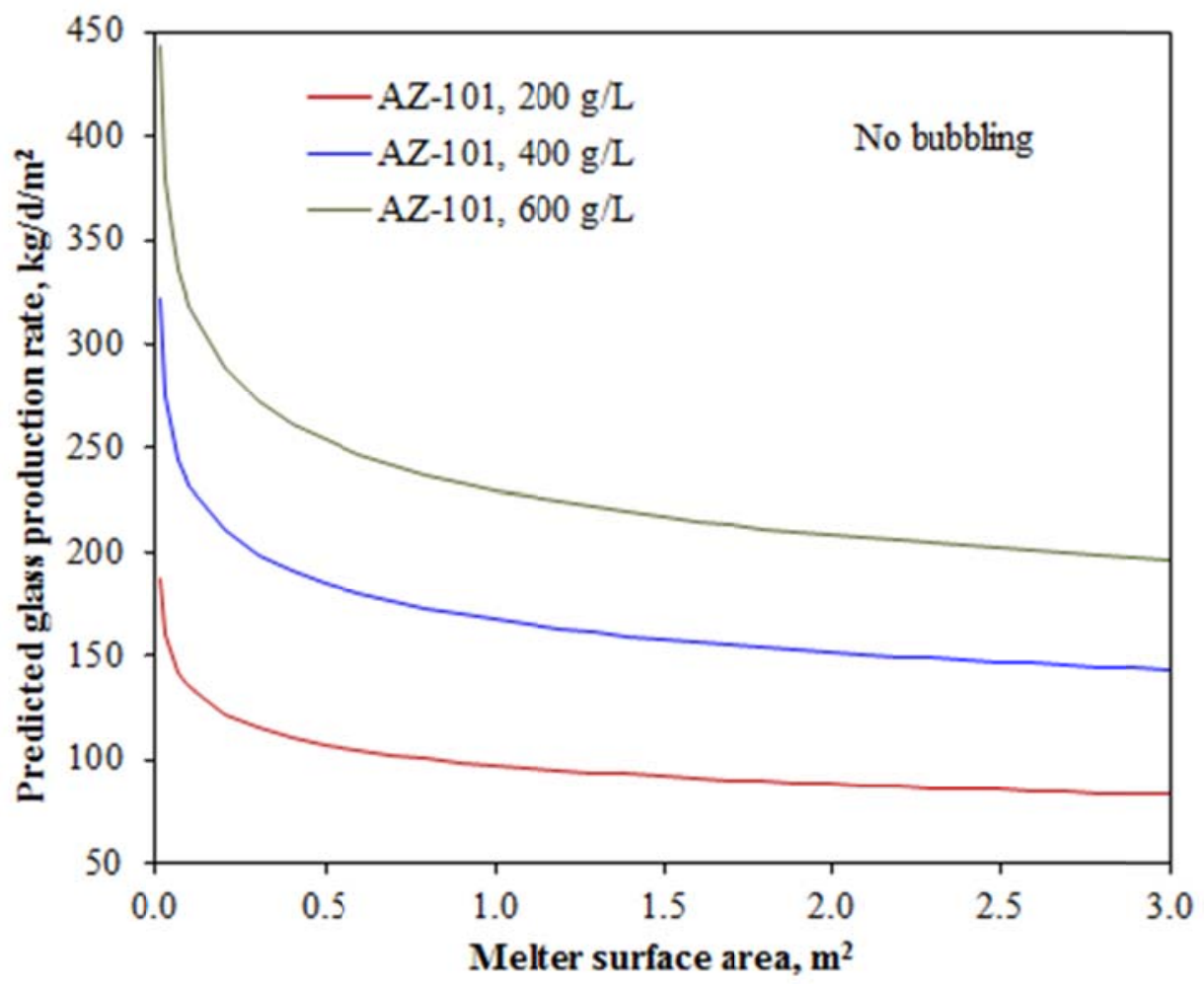

Figure 5.9. Predicted Effect of Melter Surface Area on Glass Production Rate 
Figure 5.10 and Figure 5.11 display the glass and plenum temperature as a function of time for four LSM tests performed in this study. Both the glass and plenum temperatures in general slightly increased initially and then became relatively constant in later parts of the tests except for the plenum temperature for C-106/AY-102 glass feed. The reason for erratic change of plenum temperature for C-106/AY-102 glass feed is not known. The glass and plenum temperatures observed within the present tests did not show any correlation with observed glass production rate as shown in Figure 5.12.

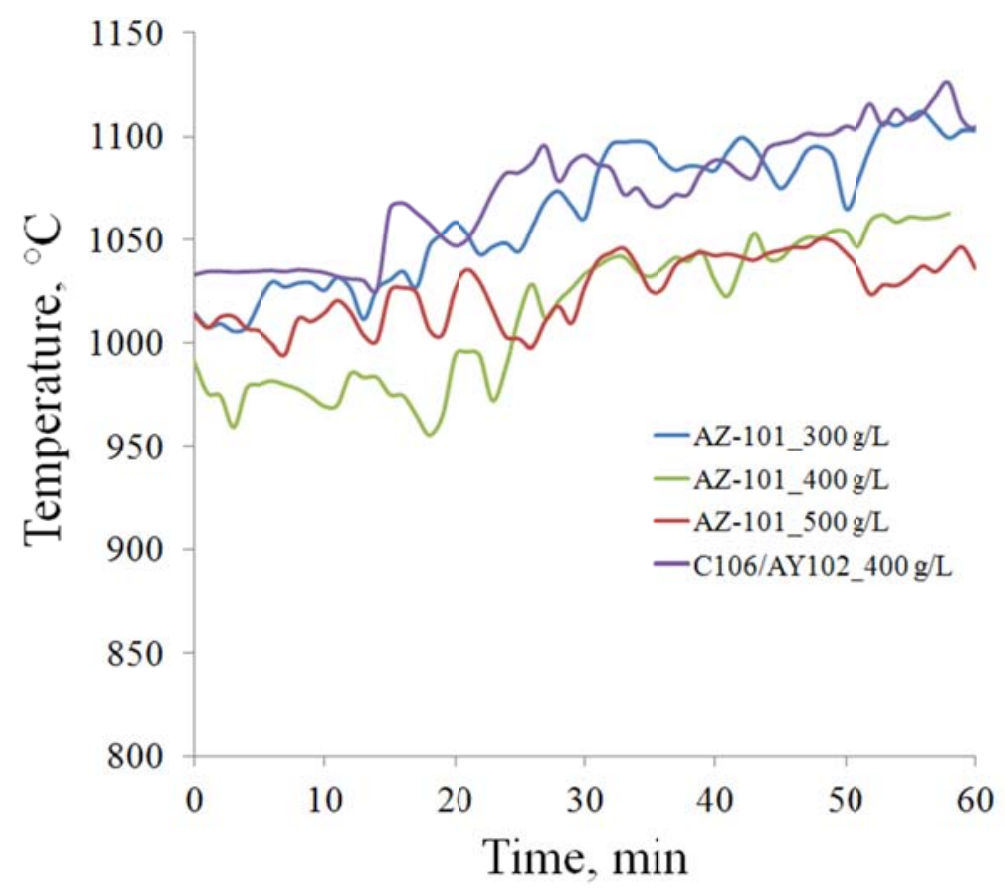

Figure 5.10. Glass Temperature versus Time after the Start of Feeding

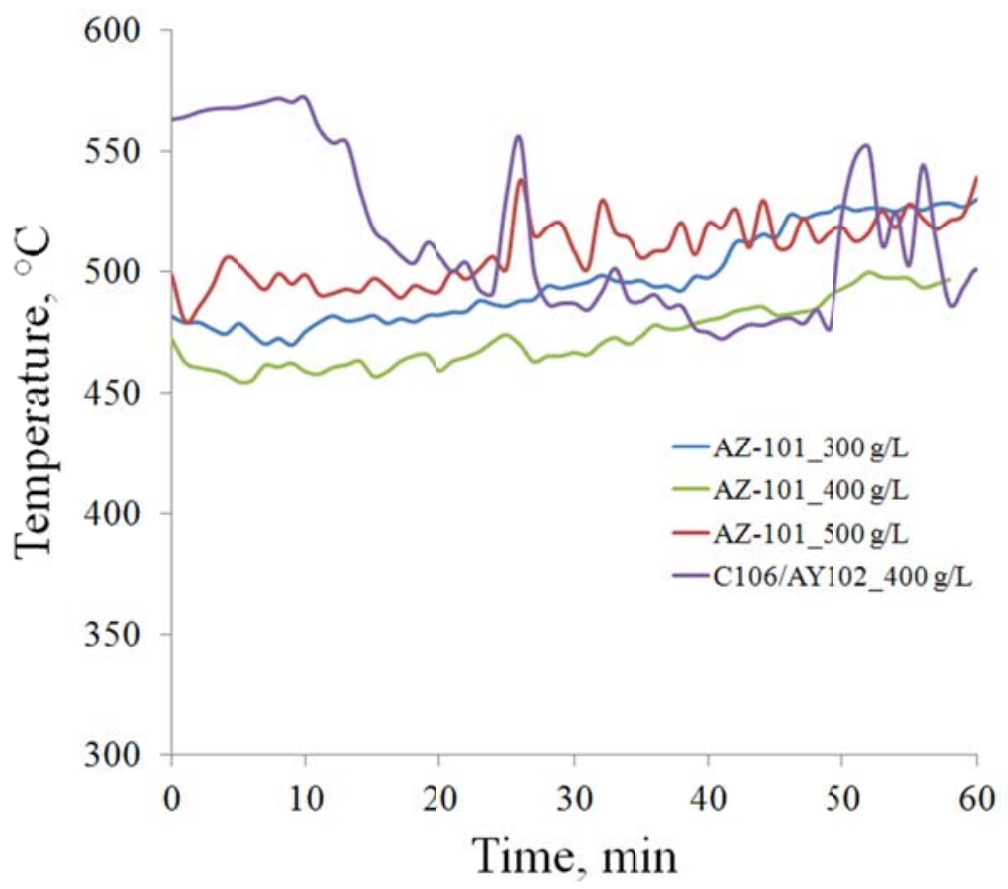

Figure 5.11. Plenum Temperature Versus Time After the Start of Feeding 


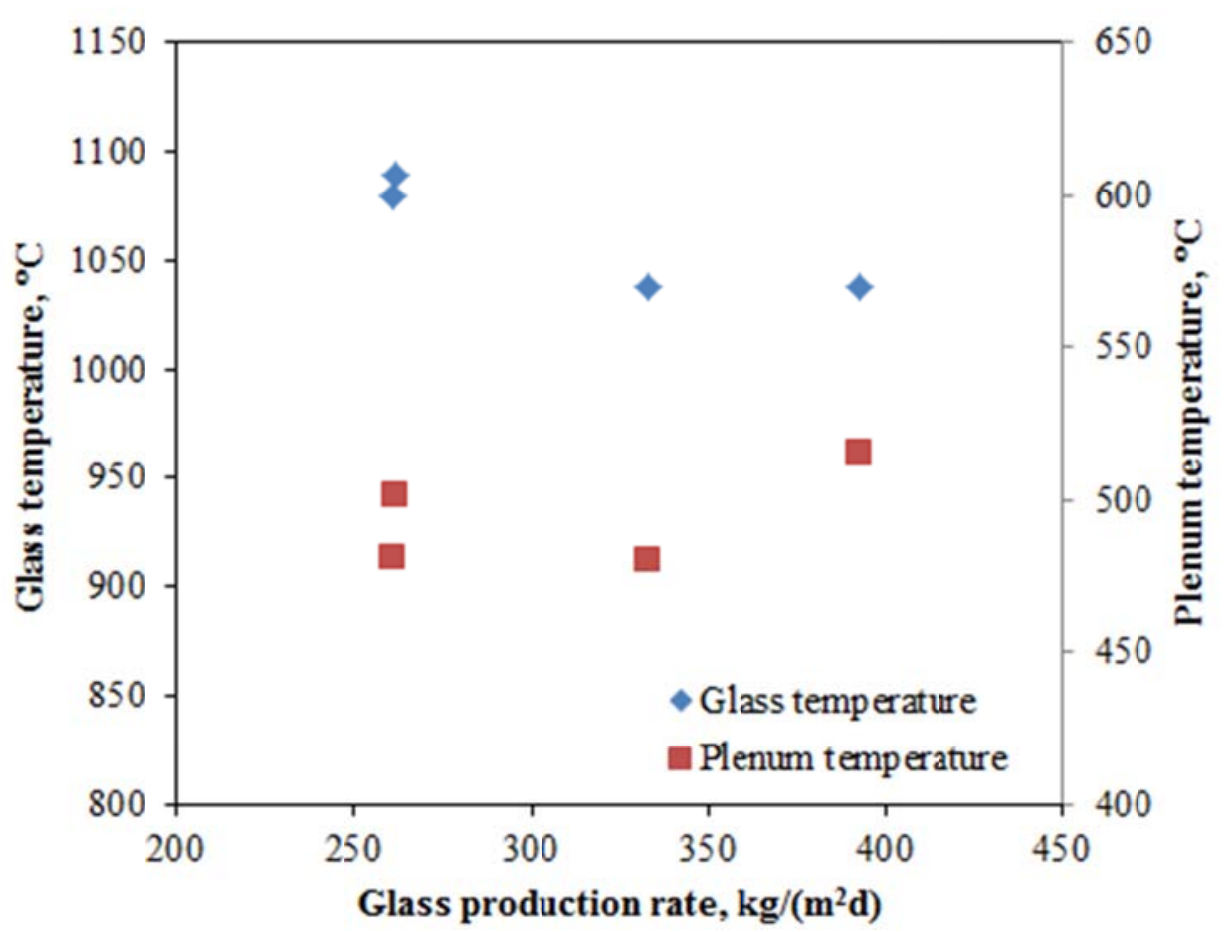

Figure 5.12. Glass and Plenum Temperatures Versus Glass Production Rate 



\subsection{Conclusions}

The melting rate data from extensive scaled-melter tests using simulated Hanford Site HLW performed for the WTP project have been compiled. Preliminary empirical model that expresses the melting rate as a function of bubbling rate and glass yield was developed from the compiled database for two waste glass feeds with most melter run data-AZ-101 and C-106/AY-102 simulated wastes. These two simulated waste melter feeds were also used for the LSM tests in this study so the melting rates determined from LSM test can be compared with those from scaled-melter tests.

The laboratory-scale melter that uses 3 or 4 in. diameter-fused quartz crucible was developed as a quick and inexpensive method to determine the processing rate of various waste glass slurry feeds. Tests with the initial setup were not successful to obtain the steady-state melting rate, although the preliminary test results provided information on the structure (morphology) of cold cap important for development of the mathematical cold-cap model. Based on these initial experiences, the following improvements were implemented:

- Increased diameter of quartz crucible

- New lift apparatus to allow fine control and precise monitoring of crucible height relative to the furnace

- Redesign of slurry feeding system to use water-cooled line outside the feeding tube

- Placement of thermocouple bundle for measurement of temperatures of the molten glass and plenum space.

The results of LSM runs with AZ-101 and C-106/AY-102 simulated HLW melter feeds performed after implementing the above improvements corresponded well with the production rates obtained from the scaled-melter tests. The present results suggest the LSM setup can be used to predict the appropriate trends in glass production rates for the development of new glass compositions or feed makeups that can increase the processing rate of the slurry feeds, although it will not give a quantitative data of large-scale tests. The improvements applied to the present setup will also make it much easier to investigate the formation of separated salt phase during cold-cap melting, which is valuable in developing glass formulations for the waste types of which loading is limited by separated salt formation. 



\subsection{References}

Bickford DF, P Hrma, and BW Bowen, II. 1990. "Control of Radioactive Waste Glass Melters: II, Residence Time and Melt Rate Limitations.” J. Amer. Ceram. Soc. 73:2903.

Chapman C. 2004. Investigation of Glass Bubbling and Increased Production Rate. REP-RPP-069, Rev. 0, Duratek, Richland, Washington.

Darab JG, DD Graham, BD MacIsaac, RL Russell, DK Peeler, HD Smith, and JD Vienna. 2001. Sulfur Partitioning During Vitrification of INEEL Sodium Bearing Waste: Status Report. PNNL-13588, Pacific Northwest National Laboratory, Richland, Washington.

Henager SH, P Hrma, KJ Swearingen, MJ Schweiger, J Marcial, and NE TeGrotenhuis. 2011. "Conversion of Batch to Molten Glass, I: Volume Expansion," Journal of Non-crystalline Solids, 357(3): 829-835.

Hrma P. 1990. “Melting of Foaming Batches: Nuclear Waste Glass.” Glastech. Ber. 63K:360.

Hrma P, J Matyáš, and D-S Kim. 2002. “The Chemistry and Physics of Melter Cold Cap.” In: $9^{\text {th }}$ Biennial Int. Conf. on Nucl. and Hazardous Waste Management, Spectrum '02, American Nuclear Society, CD-ROM.

Hrma PR, CJ Humrickhouse, JA Moody, RM Tate, MJ Schweiger, VV Mantay, TT Rainsdon, NE TeGrotenhuis, BM Arrigoni, J Marcial, CP Rodriguez, BH Tincher. 2009. Effect of Melter-Feed-Makeup on Vitrification Process. PNNL-18374, Pacific Northwest National Laboratory, Richland, Washington.

Hrma PR, MJ Schweiger, CJ Humrickhouse, JA Moody, RM Tate, TT Rainsdon, NE TeGrotenhuis, BM Arrigoni, J Marcial, CP Rodriguez, and BH Tincher. 2010. "Effect of glass-batch makeup on the melting process.” Ceramics-Silikaty, 54(3):193-211.

Hrma P, J Marcial, KJ Swearingen, SH Henager, MJ Schweiger, and NE TeGrotenhuis. 2011a. "Conversion of Batch to Molten Glass, II: Dissolution of Quartz Particles." Journal of Non-crystalline Solids 357(3):820-828.

Hrma P and J Marcial. 2011b. “Dissolution Retardation of Solid Silica During Glass-Batch Melting.” Journal of Non-crystalline Solids, 357(15):2954-2959.

Kim D, WC Buchmiller, MJ Schweiger, JD Vienna, DE Day, CW Kim, D Zhu, TE Day, T Neidt, DK Peeler, TB Edwards, IA Reamer, and RJ Workman. 2003. Iron Phosphate Glass as an Alternative Waste-Form for Hanford LAW. PNNL-14251, Pacific Northwest National Laboratory, Richland, Washington.

Matlack KS, WK Kot, F Perez-Cardenas, and IL Pegg. 2000. Determination of Processing Rate of RPP-WTP HLW Simulants using a DuraMelter ${ }^{\mathrm{TM}} 1000$ Vitrification System. VSL-00R2590-2, Rev. 0, Vitreous State Laboratory, The Catholic University of America, Washington, D.C.

Matlack KS, M Brandys, and IL Pegg. 2001. Start-Up and Commissioning Tests on the DM1200 HLW Pilot Melter System Using AZ-101 Waste Simulants. VSL-01R0100-2, Rev. 0, Vitreous State Laboratory, The Catholic University of America, Washington, D.C. 
Matlack KS, WK Kot, T Bardakci, W Gong, N D’Angelo, TR Schatz, and IL Pegg. 2003a. Tests on the DuraMelter 1200 HLW Pilot Melter System Using AZ-101 Waste Simulants. VSL-02R0100-2, Rev. 1, Vitreous State Laboratory, The Catholic University of America, Washington, D.C.

Matlack KS, W Gong, T Bardakci, N D’Angelo, W Kot and IL Pegg. 2003b. Integrated DM1200 Melter Testing of HLW C-106/AY-102 Composition Using Bubblers.” VSL-03R3800-1, Rev. 0, Vitreous State Laboratory, The Catholic University of America, Washington, D.C.

Matlack KS, WK Kot, and IL Pegg. 2003c. Melter Tests with AZ-101 HLW Simulant Using a DuraMelter 100 Vitrification System. VSL-01R10N0-1, Rev. 1, Vitreous State Laboratory, The Catholic University of America, Washington, D.C.

Matlack KS, W Gong, T Bardakci, N D’Angelo, WK Kot, and IL Pegg. 2004a. DM1200 Tests with AZ-101 HLW Simulants. VSL-03R3800-4, Rev. 0, Vitreous State Laboratory, The Catholic University of America, Washington, D.C.

Matlack KS, W Gong, T Bardakci, N D’Angelo, W Lutze, PM Bizot, RA Callow, M Brandys, WK Kot, and IL Pegg. 2004b. Integrated DM1200 Melter Testing of Redox Effects Using HLW AZ-101 and C-106/AY-102 Simulants. VSL-04R4800-1, Rev. 0, Vitreous State Laboratory, The Catholic University of America, Washington, D.C.

Matlack KS, W Gong, T Bardakci, N D’Angelo, W Lutze, RA Callow, M Brandys, WK Kot, and IL Pegg. 2004c. Integrated DM1200 Melter Testing of Bubbler Configurations Using HLW AZ-101 Simulants. VSL-04R4800-4, Rev. 0, Vitreous State Laboratory, The Catholic University of America, Washington, D.C.

Matlack KS, W Gong, T Bardakci, N D’Angelo, M Brandys, WK Kot, and IL Pegg. 2005a. Integrated DM1200 Melter Testing Using AZ-102 and C-106/AY-102 HLW Simulants: HLW Simulant Verification. VSL-05R5800-1, Rev. 0, Vitreous State Laboratory, The Catholic University of America, Washington, D.C.

Matlack KS, W Gong, T Bardakci, N D’Angelo, M Brandys, WK Kot, and IL Pegg. 2005b. Regulatory Off-Gas Emissions Testing on the DM1200 Melter System Using HLW and LAW Simulants.

VSL-05R5830-1, Rev. 0, Vitreous State Laboratory, The Catholic University of America, Washington, D.C.

Matlack KS, W Gong, and IL Pegg. 2005c. DuraMelter 100 HLW Simulant Validation Tests with C-106/AY-102 Feeds. VSL-05R5710-1, Vitreous State Laboratory, The Catholic University of America, Washington, D.C.

Matlack KS, G Diener, T Bardakci, and IL Pegg. 2006. Summary of DM1200 Operation at VSL. VSL-06R6710-2, Rev. 0, Vitreous State Laboratory, The Catholic University of America, Washington, D.C.

Matlack KS, WK Kot, W Gong, and IL Pegg. 2007. Small Scale Melter Testing of HLW Algorithm Glasses: Matrix 1 Tests. VSL-07R1220-1, Vitreous State Laboratory, The Catholic University of America, Washington, D.C.

Perez JM, CC Chapman, RK Mohr, KS Matlack, and IL Pegg. 2005. “Development and Demonstration of an Air Bubbler Design to Meet High-Level Waste Melter Production rate Requirements of the Hanford Waste Treatment and Immobilization Plant.” In: Proceedings for ICEM'05: The $10^{\text {th }}$ International 
Conference on Environmental Remediation and Radioactive Waste Management, September 4-8, 2005, Glasgow, Scotland.

Pokorny R and PR Hrma. 2010. Mathematical Model of Cold Cap-Preliminary One-Dimensional Model Development. PNNL-20278 (EMSP-RPT-007), Pacific Northwest National Laboratory, Richland, Washington.

Riley BJ, JV Crum, WC Buchmiller, BT Rieck, MJ Schweiger, and JD Vienna. 2009. “Initial Laboratory-Scale Melter Test Results for Combined Fission Product Waste, Advanced Fuel Cycle Initiative.” AFCI-WAST-PMO-MI-DV-2009-000184, Pacific Northwest National Laboratory, Richland, Washington.

Schweiger MJ, PR Hrma, CJ Humrickhouse, J Marcial, BJ Riley, and NE TeGrotenhuis. 2009. “Cluster Formation of Silica Particles in Glass Batches During Melting.” Journal of Non-crystalline Solids 356 (25-27):1359-1367.

Vienna JD, WC Buchmiller, JV Crum, DD Graham, D-S. Kim, BD MacIsaac, MJ Schweiger, DK Peeler, TB Edwards, IA Reamer, and RJ Workman. 2002. Glass Formulation Development for INEEL

Sodium-Bearing Waste. PNNL-14050, Pacific Northwest National Laboratory, Richland, Washington. 

PNNL-21005

\section{Distribution*}

No. of

Copies

2 U.S. Department of Energy

Office of Environmental Management

SP Schneider

GL Smith

5 U.S. Department of Energy

Office of River Protection

TW Fletcher

RA Gilbert

AA Kruger

BM Mauss

SH Pfaff

3 Savannah River National Laboratory

F Johnson

J Marra

DK Peeler

3 Vitreous State Laboratory

WK Kot

KS Matlack

IL Pegg

2 Washington River Protection Solutions

WG Ramsey

LE Thompson

$4 \quad$ Waste Treatment and Immobilization Plant

SM Barnes

CC Chapman

JL Nelson

LL Petkus
No. of

Copies

\section{Local Distribution}

Pacific Northwest National Laboratory

PR Bredt

WC Buchmiller

J Chun

JV Crum

PR Hrma

A Goel

BR Johnson

GB Josephson

JB Lang

W Lepry

DS Kim

J Matyas

JS McCloy

RA Peterson

LM Peurrung

BJ Riley

CP Rodriguez

JV Ryan

MJ Schweiger

GJ Sevigny

D Skorski

JD Vienna

JH Westsik, Jr.

*All distribution will be made electronically. 


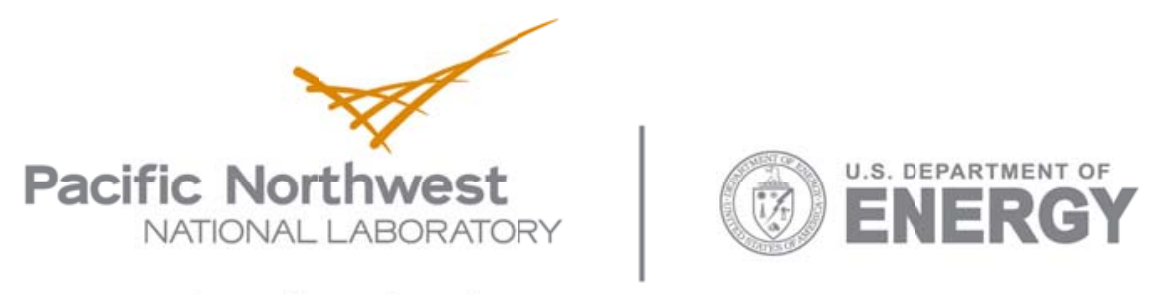

902 Battelle Boulevard

P.O. Box 999

Richland, WA 99352

1-888-375-FNNL (7665)

www.pnl.gov 